\title{
The 2008 Chilean Reform to First-Pillar Pensions
}

\author{
SALVADOR VALDÉS-PRIETO
}

CESIFO WORKING PAPER NO. 2520

CATEGORY 3: SOCIAL PROTECTION

JANUARY 2009
An electronic version of the paper may be downloaded
- from the SSRN website: Www.SSRN.com
- from the RePEc website: $\quad$ www.RePEc.org
- from the CESifo website: www.CESifo-group.org/wp




\title{
The 2008 Chilean Reform to First-Pillar Pensions
}

\begin{abstract}
Chile approved in early 2008 the replacement of her two current non-contributory subsidies for the old poor for a unified program with a pioneering design, with phase-in ending in 2012. This paper describes the political economy of this reform and evaluates it with regards to efficiency and equity. The design is analogous to one adopted in Finland in 1957, with two differences: First, the subsidy withdrawal rate in response to the individual's contributory pension benefit is lower, about 30\% rather than 50\%. Second, preserving a tradition introduced in 1975, benefits are also withdrawn in response to per capita household income.
\end{abstract}

JEL Code: H55, H53, I38.

Keywords: social security, welfare programs, political economy of reform.

\author{
Salvador Valdés-Prieto \\ Professor of Economics \\ Pontificia Catholic University of Chile \\ Santiago, Chile \\ svaldes@faceapuc.cl
}

December 31, 2008

This is the policy paper of a pair in which the companion paper (Valdés-Prieto, 2008b) provides a theory of contribution density and social insurance. The precursor paper of this one is Valdés-Prieto (2007b). I appreciate comments received in the Annual Conference of the Chilean Economics Society in Viña del Mar, September 4-5, 2008. None is responsible for the claims made in this paper. I also thank the World Bank for translating a previous version to English.

Since the author was an academic actor in this reform process, this is to some extent an insider's account. 


\section{Introduction}

The Chilean Congress approved in January 2008 the replacement of her two current non-contributory subsidies for the old poor ("first pillar") for a unified program with a pioneering design. This paper describes the policy process and evaluates the new design.

The first finding is that reform was not driven by poverty among the old. For two decades, elderly poverty in Chile has remained at levels that are half the national poverty rate for all ages. ${ }^{3}$ Controlling for her income level, Chile had one of the best old-age poverty alleviation schemes before the 2008 reform, by international standards. The main reasons are that the Assistance pension introduced in 1975 is not conditional on having made contributions, and that its amount and coverage were raised steadily during the high growth years of 1988-2005.

The paper argues that the reform took place because of a combination of four factors, two of them strongly political. The first was the government's need to mobilize voters for the 2005 presidential election. It chose a pension reform once it found a way to advertise it as a partial reversal of the pension reform of 1981, one of Pinochet's emblematic policies. For example, the Labor and Pensions Minister declared that "The deep political meaning of this reform is that citizens (that do not contribute also) have a right to a decent pension in old age,... (because) citizens have intrinsic value and dignity...(contrary to what) we were brought to believe during the authoritarian regime... Citizens are not disposable..."4. History is rather different: non-contributory pensions were introduced in Chile in 1975, by Pinochet's regime, and the level of these subsidies had already been raised gradually over the high-growth years of $1988-2005$ to $48 \%$ of the earnings of a working couple in the $40^{\text {th }}$ percentile of the earnings distribution. Despite being false, this rhetoric provided the political impetus for the 2008 reform. The governing coalition also won reelection in 2005 (second round in January 2006).

A second driving factor was the government's claim that without reform, the proportion of the elderly covered by a contributory pension would fall from $65 \%$ to $50 \%$ within 20 years, by 2025. This prediction was intended to criticize Pinochet's 1981 reform, which replaced a pay-as-you-go financed and state-managed contributory pension system, for a fully-funded and privately-managed contributory pension system. This paper analyzes this prediction and finds it wanting: the studies cited to underpin this prediction projected a different variable. The best point estimate is that the proportion of the elderly covered by some contributory pension would have remained constant from 2003 to 2025, in the absence of reform.

The leaders of the governing coalition also created a Presidential Advisory Commission (PAC) to allow experts to influence the actual content of the reform, as indeed happened. A paradoxical result was that the 2008 reform entrenched the two pension reforms introduced by Pinochet: the introduction of non-contributory pensions in 1975, and the one reform to contributory pensions in 1981. It is not surprising that leftist leaders in the governing coalition feel betrayed and ask for more radical reform.

\footnotetext{
${ }^{3}$ Barr and Diamond (2008, p. 231) assert that "Continuing and probably increasing pension poverty is (...) a key driver of the reforms". Although deficiencies existed (see section 4), the size of their average impact on elderly poverty was low. This prevented elderly poverty from becoming a driving force of the reform.

${ }^{4}$ My translation of Andrade, Osvaldo, “El Significado político profundo de la reforma previsional”, column in newspaper El Mercurio of Santiago, January 18, 2008, page B9.
} 
Two other drivers for reform were the outcome of economic research done over 1997-2004 at local universities, think-tanks and at the Superintendence of Pensions. This research governed the PAC's proposals. The first finding were large horizontal inequities in existing non-contributory subsidies for the old. The second driver was that research suggested that badly-designed non-contributory subsidies crowded out contributory pensions, due to high implicit tax rates on contributions created by fast withdrawal of noncontributory subsidies. Two competing policy solutions vied for favor: a minimum pension whose amount is proportional to each participant's contribution time (like Switzerland's first pillar in the absence of the "pension supplement"), and a linear subsidy with a constant withdrawal rate (like Finland's scheme). The PAC decided this debate in favor of the second scheme, after this author showed that it performs better in avoiding horizontal inequities (Valdes-Prieto 2006b).

The scheme adopted by Chile in 2008 differs in two ways from the one adopted by Finland in 1957. First, the withdrawal rate of the subsidy, in response to the individual's contributory pension, is about $30 \%$ rather than $50 \%$. The Chilean design also differs from those used in Sweden from 2003 and in Norway from 2010, because it has a single modest withdrawal rate, rather than two large rates (100\% and 48\%, 100\% and 60\%). Second, preserving the policy established in 1975, benefits are also withdrawn in response to the beneficiary's household position in the distribution of per capita household income. The absence of this second withdrawal rule in Scandinavia implies that large intra-household transfers and capital consumption do not reduce the subsidy. However, the Chilean reform also preserved a negative aspect of the 1975 design: it uses cliff withdrawal, with negative consequences for individual risk, horizontal equity and incentives.

The reform was also influenced by the fiscal bonanza caused by higher international commodity prices in 2004-2008. This bonanza emboldened populist demands for major increases in benefits. The paper shows how the Ministry of Finance tried to devise defenses, but failed due to technical mistakes. Thus, the size of the basic new noncontributory subsidy for the old was set at $77 \%$ of the market wage for a couple in the $40^{\text {th }}$ percentile of the earnings distribution. This likely to be too large on several counts: First, it increases income inequality between pensioners (the rich) and active workers (the poor) in the same social group. This may have helped trigger populist demands in 2007 to raise the minimum wage way above median earnings. Second, this level of benefits, which is high relative to earnings, created new incentives to reduce the density of contribution.

On the other hand, since this reform increased the adequacy of total benefits and eliminated many horizontal inequities, it increased the political stability of the overall pension system, including the funded and privately-managed portion created in 1981. A blemish in the reform process is that the Ministry of Finance never gave credible information about the fiscal costs of the reform.

Section 2 presents the history of Chilean pension policy before the 2008 reform and the trends without reform. Section 3 presents the two political arguments for reform that were operative in Chile. Section 4 presents the economic arguments for reform, which spanned both efficiency and equity. Section 5 describes the fiscal aspects of the reform, emphasizing the strategies followed by the Ministry of Finance. Section 6 describes how the unreconcilable differences among members of the PAC were "resolved" by writing a self-contradictory Report. Section 7 describes new problems created by the 2008 pension reform. Section 8 assesses the impact of the reform on the political stability of the fullyfunded and privately-managed contributory pensions. 


\section{Initial conditions}

\subsection{A brief history of Chilean pension policy before 2008}

The first contributory and mandatory old-age pension scheme for workers in the private sector was created in 1924. Initially, this second pillar featured individual accounts, partial capitalization, and "defined" benefits. ${ }^{5}$ It was managed by mixed boards in which unions and employer associations were represented. However, the unwillingness to index the benefit formula and large inflation surprises cut the pensions for the initial generations of participants. ${ }^{6}$ The benefit formula also paid zero benefits to participants that did not meet a density or vesting requirement. This was, for men, to complete 800 weeks of contribution (15.4 years) if density was above 0.5 or to complete 1,040 weeks (20 years) if density was smaller than 0.5 . For women, it was to complete 520 weeks (10 years) of contribution. The joint result was that the system paid pensions that were considerably lower than promised.

One efficient policy response to this situation would have been to restore the conditions under which pension funds obtain decent returns, namely to end financial repression and allow international capital mobility, and to introduce a subsidy for the old poor (first pillar). Instead, the reform of 1952 adopted pay-as-you-go finance, which allowed a substantial immediate increase in benefits, but only for those current old that met the restrictive density requirements. This reform saddled subsequent generations with a hidden tax (Sinn, 1999). Similarities between the 1951 and 2007 situations are mentioned in the final remarks.

In addition, the 1952 reform introduced the first subsidy for the old, a "Minimum Pension Subsidy". However, since it included a tough density requirement for accessing the subsidy, which was set equal to the density requirement described above, it cannot be characterized as "non-contributory". This reform was designed by the last government of the Radical party and the Senate's social security committee, led by then Senator Salvador Allende. Initially, the minimum pension subsidy covered the pension plan for blue-collar workers only, although it was the largest by far. The subsidy was extended in 1963 to cover all other plans (sources in Valdés-Prieto 2006c) ${ }^{7}$. Later, the subsidy was duly extended to participants in the new fully-funded and privately-managed system created in $1981 .{ }^{8}$

Since self-employment, informal employment and home production (in the case of women) were widespread in Chile throughout the 20th century (and remains so), many old poor

\footnotetext{
5 "Defined" is in quotes because political risk can make it riskier than an annuity.

${ }^{6}$ The unwillingness to grant cost-of-living adjustments originated in the inability of the plans to self-finance acceptable replacement rates. This was due to low financial returns of the pension funds (partial funding), and in turn, this was due to financial repression in 1931-1960 coupled with growing use of the inflation tax to finance government expenditure. Other regulatory interferences destroyed the local equity market, while capital controls precluded international diversification.

${ }^{7}$ The plans that joined in 1963 had a smaller vesting requirement for men, usually 10 years of contributions.

${ }^{8}$ The vesting requirement for members of the new fully-funded system was also 20 years of contributions, for both men and women. Another difference with the old contributory system was introduced: participants without non-contributory subsidies are entitled to get back their contributions plus interest.
} 
were excluded from this subsidy. In 1974, researchers published the first "Map of Extreme Poverty," which demonstrated that the State had failed to protect the poorest in the preceding decades (Molina et al, 1974). Indeed, those in extreme poverty never gained access to the minimum pension subsidy created in 1952, because they could not meet the density requirement. Despite the rhetoric, up to the early 1970s the State had given priority to middle-class groups organized by unions and the political parties. The poor who did not save voluntarily and were not aided by their children were pauperized in their old age. ${ }^{9}$

In response to this challenge, in 1975 the Pinochet Government created the "Assistance pension". This was the first non-contributory subsidy, because there was no density requirement. Targeting conditions were imposed. The 2008 reform continued this tradition. For many years, access to the Assistance pension was restricted further by a waiting list, but this requirement was eliminated by legislation passed in December 2005. As of 2007 access to the Assistance pension depended only on age and the points obtained in a "proxy" means test. Poverty is defined as residing in a household whose per capita income is less than 50 percent of the minimum pension target, and to have a score in the Social Protection Scorecard (Ficha de Protección Social, FPS) that falls short of a threshold. The first requirement targets intrafamily transfers, since a rich woman supported by her husband (or sons and daughters) or by capital income fails this test, even if her contributory pension is nil (say she did little paid work). The FPS score for an individual is determined on the basis of answers to a survey conducted by a social worker and from administrative sources.

\subsection{Was the 2008 reform driven by elderly poverty?}

A common rationale for reforms to non-contributory (first-pillar) subsidies is poverty among the old. The OECD assesses the importance of elderly poverty by comparing the poverty rates for the elderly, with the rate for overall population. In Chile, the elderly have been the age group with the lowest proportion below the poverty line for 20 years, since survey evidence became available. The 2006 CASEN survey confirmed this once again, and found that the poverty rate of the old was $45 \%$ smaller than the general poverty rate.

Table 1: Elderly Poverty Rate Compared to That of Other Age Groups, CASEN 2006

\begin{tabular}{|c|c|c|c|}
\hline Age Group & $\begin{array}{c}\text { \% below } \\
\text { indigent line }\end{array}$ & $\begin{array}{c}\% \text { non- } \\
\text { indigent poor }\end{array}$ & $\begin{array}{c}\text { \% below } \\
\text { poverty line }\end{array}$ \\
\hline Age 60 or over & $1.3 \%$ & $6.2 \%$ & $7.5 \%$ \\
\hline All ages & $3.2 \%$ & $10.5 \%$ & $13.7 \%$ \\
\hline Ratio All ages /Elderly & 2.5 times & 1.7 times & 1.8 times \\
\hline Children ages 0-3 & $5.2 \%$ & $16.7 \%$ & $21.9 \%$ \\
\hline $2^{\text {nd }}$ least poor group: (ages 45-59) & $2.1 \%$ & $7.2 \%$ & $9.3 \%$ \\
\hline
\end{tabular}

Source: CASEN 2006, results available in www.mideplan.cl

Table 1 shows that elderly poverty in Chile has remained for two decades at a level that is half the national poverty rate for all ages. It has been objected that the poverty line shown in Table 1 does not take into account the differences in cost of living for children and senior

\footnotetext{
${ }^{9}$ As section 4.2 argues, this may have been exacerbated by the design of the 1952 minimum pension subsidy.
} 
citizens, and does not take into account economies of scale at the level of the household. However, Litchfield (2002) corrected for these two items and found that the marginal impact over a household's income of the presence of an elderly person is substantially positive, rather than neutral or negative. Specifically, Litchfield found that the presence of a male elderly raises household income by $5.7 \%$ in the urban sector and by $14.6 \%$ in the rural sector, ceteris paribus. The presence of a female elderly raises household income by even more: $12.4 \%$ in the urban sector and by $22.5 \%$ in the rural sector. ${ }^{10}$ To this, the effect of age itself must be added: this impact is $1.16 \%$ per additional year of age in the urban areas and $0.62 \%$ per additional year of age in the rural areas. Thus, the message of Table 1 is robust: the elderly are the age group with the smallest poverty rate in Chile. ${ }^{11}$ Thus, the first finding of this paper is that the 2008 reform was not driven by poverty among the old.

Barr and Diamond (2008, p. 231) assert that "Continuing and probably increasing pension poverty is (...) a key driver of the reforms". Although deficiencies existed (see section 4), the facts in Table 1 imply that the size of their average impact on elderly poverty was small. During the policy debate, elderly poverty never was a driving force. At the same time, the deficiencies create horizontal inequities that may be used to build momentum for reform, even if the impact on average poverty is small. This is the thesis proposed in section 4.

Barr and Diamond also assert that uncertainty about investment returns in the contributory segment, and political risk about the level of the Assistance pension in the non-contributory segment, were a second driver of the reforms (2008, p. 231). However, these two sources of uncertainty were not debated, and equally important, were not addressed by the reform. Indeed, investment returns are implicitly insured at the margin at the rate of $30 \%$ after the reform. This rate is below the $100 \%$ implicit insurance rate for those on minimum pensions before the reform. Political risk did not change: the rules for adjusting benefit levels in the new non-contributory pension are those that apply to the minimum pension since 1992.

The relatively low poverty rate among the elderly is a success of Chilean society, since in most other emerging countries the elderly have higher poverty rates (World Bank 2000). The contribution made by non-contributory subsidies can be assessed by their "coverage of benefits" and by the average size of those benefits. In 2003, 18.6 percent of senior citizens received Assistance pensions (GOCh, 2006, p. 6). Another 23 percent received minimum pension subsidies in 2004. Most of them are pensioners in the old system, who obtained a minimum pension supplement. ${ }^{12}$ Thus, Chile's noncontributory subsidies for the old covered some 41.6 percent of the elderly population in 2004. Starting in May 2006,

\footnotetext{
${ }^{10}$ See Table 11 in Litchfield (2002).

${ }^{11}$ The PAC Report (p. 52) failed to become aware of Litchfield's evidence and embraced the critics' position. The PAC argued that the larger health care expense of senior citizens is not taken into account by Table 1. However, it ignored the lower expense in transportation, food and other items that benefits the old. Although the PAC complains that inflation in drugs and medical services is higher than in other items of the CPI, it fails to correct for the growing quality of drugs and services. The PAC argued that the imputed rent on housing ignores the illiquidity of housing wealth, and that this affects the old by more because they own more housing. However, it ignored the fact that housing is only partially illiquid, because rooms can be let and can be offered to family members that provide monetary support. Inattention to Litchfield's result compromises the value of this section of the PAC's Report.

${ }^{12}$ See INP Statistical Annual Report in www.inp.cl, and sources in Valdes-Prieto 2006b and 2006c. These figures can be added because receiving both pensions is prohibited. This incompatibility rule is enforced.
} 
coverage should have been significantly larger, due to the $10 \%$ extraordinary real increase in the amount of the Assistance pension and of the Minimum Pension Goal that were legislated in a separate reform approved in April 2006, but no measurement is available yet. These figures make Chile one of the developing countries with larger coverage in its noncontributory subsidy system for the old poor. ${ }^{13}$ Regarding the average size of existing non-contributory subsidies, it was also appreciable. In January 2006, the amount of the Assistance pensions earned by a couple was $48 \%$ of the $40^{\text {th }}$ percentile of earnings for active couples (see table 4 below).

A major share of this success can be attributed to the subsidies created in 1952 and 1975, led by politicians with radically opposing views. The important technical aspects are that the Assistance pension is not conditional on having made contributions, and that its amount and coverage were raised steadily in the high growth years of 1988-2005.

If a demand to reduce poverty had been a driver for reform in Chile, the budget priority would have been to help the poor in other age groups, especially children (see Table 1). Since the child poverty rate is nine times larger (21.9\%), a progressive aim for this reform cannot be taken at face value. Of course, the 2008 reform is expected to reduce poverty rates among the elderly even further, possibly to $2.5 \%$ according to recent simulations.

\section{Two political drivers of the 2008 pension reform}

This section reviews the two "political" factors that drove the 2008 pension reform: (3.1) the governing coalition's need to mobilize voters for the 2005 presidential election. It chose a pension reform because it could be advertised as a partial reversal of the pension reform of 1981, one of Pinochet's emblematic policies; and (3.2) the assertion by the government that in the absence of reform, the proportion of the elderly that would hold a contributory pension would fall from $65 \%$ to $50 \%$ within 20 years.

\subsection{An emotional banner for the 2005 presidential election}

By the end of 2004, before the presidential campaign, the Superintendence of Pensions had readied a project of law to reform pensions that did not differ much from the final project presented in December 2006. That project was based on recent research made in academia, think-tanks and the Superintendence itself ${ }^{14}$. However, in January 3, 2005, the Minister for the Presidency announced that pension reform would not be presented immediately, but rather would be the major project of their coalition for the next period, provided that it won the presidential election of December 2005. ${ }^{15}$ Thus, the decision to start a reform process was not taken by Michelle Bachelet’s government, who took office in March 2006. Rather,

\footnotetext{
${ }^{13}$ The only developing countries with first-pillar subsidies with greater coverage are Brazil's "rural pension” and the first pillars of South Africa, Namibia, and Mauritius (Poblete, 2005). The Bolivian subsidy for the elderly, which is paid only once per year, has $100 \%$ coverage.

${ }^{14}$ Source: newspaper El Mercurio of Santiago, page B2 of January 14, 2005,

${ }^{15}$ Source: newspaper El Mercurio of Santiago, front page of January 03, 2005. Undersecretary Dockendorf revealed that in the last meeting of the political committee with President Lagos, it was decided not to initiate this reform during 2005.
} 
it was taken in late 2004 by the center-left coalition's party leaders and President Lagos. The potential contribution to reelection was a major driver of this reform.

The reason to postpone reform that was offered publicly by the government, was that since 2005 was also a parliamentary election year, a debate in Congress in 2005 would be "too influenced by populism". This argument proved wrong, since most presidential candidates made populistic promises related to pensions in the 2005 campaign.

Privately, the government also argued that postponing reform was needed because the members of parliament standing for reelection would be thirsty for campaign donations. Aattempting this reform in 2005 would give interest groups excessive influence over the voting behavior of Congress, as it had happened in 1997. This concern is plausible.

The welfare-state symbolism was explicit and public during the campaign: the center-left argued that since the Lagos government had passed in 2003 a health reform that increased the role of the State (called AUGE), it would be fitting that the next government of the coalition would pass a pension reform that also increased the role of the State. ${ }^{16}$

During election year 2005, the pension reform promised by candidate Bachelet was advertised as an opportunity to reverse (partially) one of Pinochet's most emblematic policies, the pension reform of 1981. In the 1981 reform, contributory pensions for the middle classes (the "second" pillar) were converted from pay-as-you-go finance and state management by a legal monopoly, to fully-funded finance and private management by multiple profit-oriented firms among which participants can choose. ${ }^{17}$

To understand why a reversal of pension policy was electorally significant in the 2005 campaign, it is useful to recall that the center-left coalition which gained power in 1990 (and had governed until the 2005 election) combines old-style-left grass-roots with social democratic liberal "center-left" party elites. In 1989-90, these elites decided to retain the overall liberal capitalist economic system imposed by Pinochet, including the pension reform of 1981 and a focus on maximizing economic growth. Income redistribution goals were given only lip service, and the old-style left was pacified with cash transfers and symbolic measures related to the human-rights abuses of Pinochet. This critical decision was presented by the elite to their own grass-roots as one of necessity rather than conviction, but in private the elite expresed a social democratic world view.

As of early 2005, the rank-and-file members of the center-left felt frustrated that their aspirations about reversal of Pinochet's policies had been postponed for so long, despite 15 years in power (from 1990). Their willingness to mobilize in elections had fallen. The coalition's elite found that claiming that the 1981 pension reform would now be reversed

\footnotetext{
${ }^{16}$ In 2005 it was added that the Frei government (1994-2000) had passed an educational reform that increased the role of the State (called the "full-time" investment). The student protests of 2006 ended such analogies. ${ }^{17}$ This new "quasimarket” is heavily regulated, both explicitly and implicitly, by a new Superintendence. Chileans were also allowed to choose to remain in the old system, on an individual basis, but a heavy tax was imposed on those that chose to remain: the implicit labor tax needed to service the hidden debt created by the introduction of pay-as-you-go finance was reduced only for those that chose the new system. In exchange general taxes were raised, but this affected all equally, even those that continued to pay high labor taxes.
} 
and that the State would be brought back to the forefront was a potent symbol of revenge on Pinochet. This symbolic operation motivated the grass-roots to fight the 2005 election, and also helped nudge the Communist Party to add its small electorate to the center-left's. The flavor of the campaign is conveyed by the declarations of the Minister for Labor and Pensions reproduced in the Introduction.

This strategy helped the center-left coalition to win the 2005 presidential election. It was also a force for convincing left-wing members of Parliament to approve the pension reform when it reached Congress, during 2007.

After winning, the leaders of the governing coalition created a Commission with the purpose of allowing experts to influence the actual content of the reform. The "Presidential Advisory Commission on Pension Reform" (PAC) had 15 members, it was heavily loaded with economists from the main positions in the political spectrum, including about a third people with strong links to the private pension fund industry. The representation of labor lawyers and committed left wingers was small, despite the electoral result.

Because of this, one of the paradoxical results of the 2008 reform was entrenchement of the two pension reforms adopted by Pinochet, one in 1975, creating non-contributory pensions, and the other in 1981, creating a fully-funded, privately-managed and defined-contribution system for the middle classes. This system was also strengthened in the 2008 reform by other measures, such as further liberalization of overseas portfolio investment. ${ }^{18}$

The main reform of 2008 was to rename, expand and redesign Pinochet's Assistance Pension. The new name is "Solidarity Pension". The center-left elite rejects this description arguing that fiscal expenditure on the Solidarity pension will be "much larger" than on the Assistance pension. However, the fiscal cost of non-contributory subsidies increases only to 1.5-2.0\% of GDP, from about 1.1\% of GDP without reform, because the center-left elite chose to index benefits in the new Solidarity Pension to prices, not wages (see section 5). Both levels are the rather modest by international standards.

The PAC proposal, which operated only between March and July 2006, cleansed most of the populist promises made during the presidential campaign of 2005. This cleansing led the left to feel betrayed by the center-left party elites, once again ${ }^{19}$. Distrust increased within the coalition. One result has been that in exchange for the approval of the reform in early 2008, the left demanded as symbolic compensation that the government propose a law to create a state-owned pension management firm. This is a symbolic demand, because no evidence has been provided that a state-owned AFP would have positive redistributional and efficiency effects. ${ }^{20}$ The center-left elite has gone alone with this demand, but without

\footnotetext{
${ }^{18}$ Other changes include increasing fiscal incentives for employer-based pensions of the DC type (like those for 401 (k) plans in the U.S. but somewhat less regressive) and an extension of the mandate to contribute to honoraria income reported to the Tax Authority. Analysis of those changes is outside the scope of this paper. ${ }^{19}$ After a transition ending in 2015, the Minimum Pension Subsidy will have disappeared and the last trace of the social policies led by ex-President Salvador Allende in 1952 will be gone. This fact has not yet transpired to the grass-roots in the left.

${ }^{20}$ To the contrary, the evidence from Uruguay suggest it will have negative effects on both counts. Regarding equity, the state-owned AFP charges much lower fees than the private AFPs, but only high earners have
} 
conviction because the 2008 reform adopted a better approach: auctioning service for a substantial chunk of participants (Valdes-Prieto, 2005). In 2008, the international financial crisis led left-wing leaders to replace their demand for a state-owned AFP, for an option to return to a pay-as-you-go financed scheme.

\subsection{Fears about falling coverage of contributory benefits}

A legitimate concern with any contributory pension plan for the middle class is that it may fail to provide adequate pensions, relative to former earnings (replacement rate). This may happen because of low density of contribution. Uneven density of contribution across large segments of participants is also an important source of dissatisfaction with contributory plans. This can be a powerful driver for reform.

In a campaign visit to New York in January 2005, the then presidential candidate Michelle Bachelet declared that "the Chilean social security model is in crisis", because " 50 percent of the retired persons in our country are going to have pensions that fall below decent levels" (newspaper El Mercurio, January 12, 2005). She was backed up by government officials that emphasized that this crisis would occur only in the AFP system, not in the old system, so it was a "design flaw" of the AFP system. These assertions had an effect even on rival presidential candidates. Several declared themselves "worried" by these figures, and promised in their first TV debate to "reform pensions".

The leftist grass-roots members of the center-left coalition were mobilized when they heard what they wanted: that Pinochet's pension reform of 1981 would fail by 2025 if left alone, because coverage would fall from 65\% to 50\%. The 2008 reform promised to bring in the State to avert disaster. In the Message to Congress of its project of law, the Chilean Government stated that in the absence of reform "the available projections show that, of the elderly population, the group covered by a contributory pension would decline from the current 65 percent to around 50 percent by 2020 (2025)" (GOCh, 2006, p. 6).

These views seem to have been an important driver of reform, to prevent a future crisis. This section finds that the claim is false. There are two types of mistakes. First, statements about the replacement rate of contributory pensions alone, such as the government's, are a flawed measure of the overall income replacement rate, which is what matters. ${ }^{21}$

switched AFP to take advantage of this. Regarding efficiency, a state-owned AFP may introduce partypolitical pressures in decisions taken by the shareholders' assemblies or creditor's assemblies in large local firms where they have substantial voting power. Those decisions include fights for corporate control, mergers, and designation of board members.

${ }^{21}$ This was acknowledged by Berstein, Larraín, and Pino, in the November 2005 version of their study, whose abstract warns that the elderly have other income sources: "(many of the elderly) will not necessarily be in a situation of vulnerability, in that they have other income sources with which they can finance their old age. In fact, some 30 percent of women over the age of 70 receive widows 'pensions today." Apparently this was not known by the Budget Director, Mr. A. Arenas de Mesa, who stated publicly that "the sum of recipients of Assistance pensions and beneficiaries of pensions equal to or less than the minimum pension (goal) ... will be directly dependent on the State” (Arenas, 2004, p. 105). This fails to take into account other income sources. 
New Zealand provides an example: in that country, only $40 \%$ of the elderly receive employer pensions of a significant $\operatorname{size}^{22}$ (for the $40 \%$ figure, the cutoff size in pension wealth is NZ\$ 80,000 - about US\$ 53,000). Despite the fact that the $40 \%$ figure is more modest than in Chile, is hard to believe that New Zealand's senior citizens have lower replacement rates than Chilean senior citizens. ${ }^{23} \mathrm{~A}$ comparison should take into account differences in the share of individuals that save voluntarily (in the form of housing, agricultural land, businesses, financial assets), differences in non-contributory subsidies ${ }^{24}$, and differences in intra-family transfers.

Income sources different from contributory pensions are important in Chile. According to the CASEN 2000 survey, 19.5 percent of the elderly did not receive any pension but had own income exceeding the minimum pension. Another 12.8 percent of the elderly do not receive any pension, did not have incomes of their own above the minimum pension, but lived in a household where per-capita income exceeded the minimum pension. This group includes women who worked all their active lives in home production, and subsequently share in their spouse's pension, without receiving a pension of their own until he passes away (Valdes-Prieto, 2006b) ${ }^{25}$.

The remainder of this section focuses on the second type of mistakes, which is mismeasurement of coverage of contributory benefits alone.

\section{Measuring coverage of contributory benefits in Chile}

Coverage of contributory benefits is defined as the percentage of the elderly that receive contributory pensions above some threshold amount or some proportion of former earnings. Because of limited data sources, the only threshold that can be chosen for this purpose is the minimum pension goal.

From 1981 to the present three contributory pension plans have coexisted in Chile: (1) the old system financed by pay-as-you-go, populated by those who chose not to switch to the system created by Pinochet's government in 1981; (2) participants in the fully-funded and privately-managed system created in 1981 (the AFP system); and (3) members of special employer plans for the Police, the Armed Forces, detectives and prison wardens. Thus, coverage of contributory pensions $C C P$ is:

$$
C C P_{t} \equiv \frac{C_{t}^{\text {Old System }}+C_{t}^{A F P}+C_{t}^{\text {SpecialeP }} n e t}{\left(C_{t}^{\text {Old System }}+C_{t}^{A F P}+C_{t}^{\text {SpecialEP }} n e t\right)+N C_{t}}
$$

\footnotetext{
${ }^{22}$ See McCulloch, Brian (2006) “A Presentation for the Singapore Central Provident Fund”, http://www.treasury.govt.nz/publications/informationreleases/kiwisaver/background/ks-sing-mcculloch.ppt . Slide 14 shows that the size of pension wealth becomes non-negligible only from ventile $\mathrm{N}^{\mathrm{o}} 13$ onwards.

${ }^{23}$ On the other hand, in 2007 New Zealand's government introduced an additional voluntary contributory system, called Kiwisaver. The aim is to raise replacement rates for lower middle-income groups.

${ }^{24}$ This subsidy for the elderly in new Zealand is universal since 1935, is financed from general taxation, and its level is 32.5\% of national average earnings. This level is similar to the Chilean Minimum Pension Goal. ${ }^{25}$ The hypothesis that most of these elderly received transfers from spouses or children is supported by the sex composition of this group, and by the high prevalence of survivorship pensions.
} 
where $N C_{t}$ is the number of elderly that are "not covered" by any of the contributory plans, in the sense defined above; and where $C_{t}^{i}$ is the number of elderly that receive benefits at the "covered" level or higher in plan $i$ as of date $t$ (i = Old system, AFP system and Special employer plans). The qualifier "net" is attached to special employer plans because after separation from the plan's sponsor, many of their participants continue working for other employers, where they contribute for a second pension.

Certainly, the assertion that "of the elderly population, the group covered by a contributory pension would decline from the current 65 percent..." is a statement about $C C P$ (see eq. 1). Now define the combined two-pillar coverage rate, $C 2 P$ :

$$
C 2 P_{t} \equiv C C P_{t}+\frac{N C_{t}^{\text {with Assis tance Pension }}}{\left(C_{t}^{\text {Old System }}+C_{t}^{A F P}+C_{t}^{\text {SpecialEP }} n e t\right)+N C_{t}}
$$

where $N C_{t}^{\text {with Assistance Pension }}$ is the number of the elderly that receive an Assistance Pension (subsidy). Note that $N C_{t}$ with Assistance Pension is a proper subset of $N C_{t}$. Since receiving the Assistance Pension is incompatible with receiving any contributory pension at the same point in time, the sum in eq. (2) does not involve double counting.

Now check the evidence. First, the government reports that the combined two-pillar coverage $C 2 P$ "has remained at about 76 percent between 1992 and 2003", based on the CASEN surveys. This is a statement about $C 2 P$. According to eq. (2), $C C P$ can be obtained from $C 2 P$ by subtracting the coverage Assistance pensions. These had a coverage rate of $18.6 \%$ in 2003 (GOCh 2006, p.6). Thus, $C C P$ was about $57.4 \%$ in 2003, not $65 \%$.

A second estimate starts from the CASEN survey for 2000. It reports that $66 \%$ of those aged 65 or more receive some pension, so $C 2 P_{2000}=0.66$ (Beyer and Valdes-Prieto 2004, p. 33). Subtraction of the number of Assistance pensions, which for 2000 is estimated at $15.6 \%$ of the elderly, ${ }^{26}$ implies a $C C P_{2000}$ of $50 \%$, way below $65 \%$.

A third estimate is obtained from administrative records, by adding the number of pensioners in the old and new contributory systems, and the employer pensions paid by the Armed Forces, the Police, the Detectives Corps and Prison Wardens. This sum is $65 \%$ for 2004 (Valdés-Prieto, 2006b). However, this sum is larger than $C C P_{2004}$ because it does not use $C^{\text {Special EP }}$ net. In other words, the beneficiaries of special employer plans that also work for other employers and build a second contributory pension have not been netted out. Although there is no reliable data about the extent of double-counting, it could reach $5 \%$.

Thus, all three estimates for $C C P$ in Chile before the reform are well below the $65 \%$ claimed by the government. Our best estimate is $57.4 \%$ for 2003 . This bias in the initial condition cuts in half the future fall in $C C P$ projected by the government.

\footnotetext{
${ }^{26}$ The coverage of Assistance pensions grew from 7.7\% to 18.6\% between 1992 and 2003, because the Government increased the number of Assistance pensions. The interpolation for 2000 is $15.6 \%$.
} 
The second aspect of the claim by the Government was that "the available projections show that, of the elderly population, the group covered by a contributory pension would decline ... to around 50 percent by 2020 (2025)" (GOCh, 2006, p. 6). In a number of declarations to the media, government officials identified the source of their projection for 2025: the study by Berstein, Larraín and Pino (2004). ${ }^{27}$ Beyer and Valdes-Prieto (2004) also reported this ratio, in a less direct manner (see Appendix). However, both sources report a different ratio, namely $Q$ :

$$
Q_{t} \equiv \frac{C_{t}^{A F P \text { with no MPSubsidy }}}{N C_{t}^{\text {Participants AFP }}+C_{t}^{A F P \text { with some MPSubsidy }}+C_{t}^{\text {AFP with no MPSubsidy }}} \approx 0.50 \text { for } t=2025
$$

To understand $Q_{t}$, note that each elderly person that owns an individual account in the AFP system can be assigned to one among three mutually exclusive groups: first, participants that do not comply with the requirement of contributing for 20 years and whose balance at pension age is too small to self-finance a minimum pension amount. They are not covered and their number is $N C_{t}^{\text {Participants } A F P}$; second a group that does comply with the 20-year contribution requirement and gets a positive subsidy. Since each one in this group contributed for at least 20 years, the contributory component of each pension is substantial and the subsidy is small. Their number is $C_{t}^{A F P}$ with some MPsubsidy ; third, a group that self-finances a pension above the minimum pension amount. Their number is $C_{t}^{A F P}$ with no MPsubsidy. The last two groups are covered at the minimum pension level or more, so the sum of the last two groups is $C_{t}^{A F P}$, already used in equations (1) and (2).The $Q$ ratio defined by (3) is not comparable to the $C C P$ defined in (1), since both the numerator and denominator differ.

There is an even stronger problem: the value of $Q_{t}$ has no impact on the value of $C C P_{t}$. The Appendix shows that:

$$
\begin{array}{r}
C C P_{t} \equiv \frac{1-\beta_{t}+\alpha_{t} \cdot R_{t}}{1+R_{t}} \quad \text { for any value of } Q_{t} \text {, where } \\
R_{t} \equiv \frac{N C_{t}^{\text {Participants AFP }}}{C_{t}^{\text {AFP with some MPSubsidy }}+C_{t}^{\text {AFP with no MPSubsidy }}}
\end{array}
$$

$\alpha_{t}$ is the number of contributory pensions from the old system plus special employer plans, divided by all the elderly, as of date $t$; and $\beta_{t}$ is the number of non-participants in any contributory system divided by all the elderly, as of date $t$.

In any three-way allocation, ratio $R_{t}$ is independent from ratio $Q_{t}$. Since $C C P_{t}$ is independent from ratio $Q_{t}$, it is impossible to infer any value for $C C P_{t}$ from $Q_{t}$, as the government did. Therefore, the government's projection is certainly wrong.

\footnotetext{
${ }^{27}$ One example is the quote from Arenas (2004) given above. Another is that the web page of the Department of Economics of the University of Chile, which ran the survey that originated the data for the Berstein et al study, claims that this study triggered the 2008 pension reform. See www.proteccionsocial.cl
} 
Equation (4a) also allows us to project $C C P_{2025}$ on the basis of $R_{t}, \alpha_{\mathrm{t}}$ and $\beta_{\mathrm{t}}$. The Appendix reports plausible assumptions that suggest a central value of $\alpha_{2025}=0.15$. Sensitivity analysis is done with values of 0.12 and 0.20 . According to the PRIESO survey, $\beta_{2000}=$ 0.275 . This figure is likely to fall over time as the employment rate for women rises, as the AFP system matures so more individuals contribute at least once in their lifetime, as economic development increases the attractions of covered jobs, and as the new mandate to "formal" independent workers to contribute is applied. For these reasons, sensitivity analysis for $\beta_{2025}$ is done with lower values and only 0.22 and 0.17 are considered.

Berstein et al and Beyer et al differ markedly regarding the ratio $R_{2025}$. Berstein et al reports $R_{t}=0.667$ for 2025, while Beyer et al report $R_{t}=0.389$ for a steady state. Table 2 reports the implications for $\mathrm{CCP}_{2025}$, including sensitivity analysis.

\section{Table 2: New projection of coverage of contributory pensions for 2025}

\begin{tabular}{lrrrrrr}
\multicolumn{4}{c}{$\mathrm{R}_{2025}=0.667$} & \multicolumn{3}{c}{$\mathrm{R}_{2025}=0.389$} \\
\multicolumn{1}{c}{$\mathbf{C C P}_{2025}$} & $\beta=0.17$ & $\beta=0.22$ & $\beta=0.275$ & $\beta=0.17$ & $\beta=0.22$ & $\beta=0.275$ \\
$\alpha=0.12$ & $54.6 \%$ & $51.6 \%$ & $48.3 \%$ & $63.1 \%$ & $59.5 \%$ & $55.6 \%$ \\
$\alpha=0.15$ & $55.8 \%$ & $52.8 \%$ & $49.5 \%$ & $64.0 \%$ & $60.4 \%$ & $56.4 \%$ \\
$\alpha=0.20$ & $57.8 \%$ & $54.8 \%$ & $51.5 \%$ & $65.4 \%$ & $61.8 \%$ & $57.8 \%$
\end{tabular}

The central values in these projections for $C C_{2025}$ are $60.4 \%$ for Beyer et al and $52.8 \%$ for Berstein et al. Given an initial condition of $57.4 \%$ for 2003, these central values suggest that $C C P$ would either fall by 4.6 percentage points or rise by 3.0 percentage points over the coming two decades, in the absence of reform. Taking account of uncertainty, our best projection for 2025 is that in the absence of reform, the $C C P$ rate would have remained constant over 2003-2025.

The findings in this section show that the Chilean reform process was politicized and that rational debate was not always foremost in most minds. Coverage figures are poorly understood by government officials, politicians and journalists. ${ }^{28}$ The Report of the Presidential Advisory Commission on Pension Reform repeated most of the mistakes identified in this section. Such a process can lead to substantial policy mistakes. One lesson for other countries is that production of comprehensive coverage data, and its regular dissemination in a way that is understood by public opinion, may reduce these dangers.

\section{Aspects of the 2008 reform driven by economic research}

The 15 experts in the PAC could see how passions had been exploited by politicians, but also saw an opportunity to bring efficiency and equity criteria back to the fore. Indeed, the most dramatic statement of the Presidential Advisory Commission's Report was that "the AFP system is not in crisis”, contradicting the claims made during the presidential

\footnotetext{
${ }^{28}$ Among the foreign reports that repeated the flawed numbers are those published in the New York Times (January 9, 2006, Larry Rohter) and in La Tribune of Paris (December 12, 2006, Lysiane Baudu).
} 
campaign (PAC Report, July 2006). This quenched some of the passions stirred to win the 2005 campaign. This section reviews the economic research that drove the PAC report, which was hastily built over the three months that ended in July 2006.

Most of the economic research reviewed here was first presented at an international conference organized by Centro de Estudios Públicos and the Superintendence of AFPs (the regulatory body for the funded pension system). It took place in Santiago, November $11-12,2004$. This research shifted the focus of the reform from the contributory to the noncontributory pillar.

\subsection{Crowding-out of contributory pensions by non-contributory subsidies}

Research by Beyer and Valdés-Prieto (2004) was the first to emphasize a connection between insufficient density of contribution to old-age pensions, and high withdrawal rates in the existing non-contributory subsidies. "Density of contribution" is defined as the share of hours in a working life during which the person contributes to some contributory old-age system. When the mandate to contribute is not fully enforced by the State, or if important groups such as the self-employed are exempted, density becomes endogenous. Enforcement is limited by technical constraints, or may be relaxed by benevolence if many evaders are poor, which can even lead to exemptions. In Chile, the self-employed are exempt, and the proportion of the active labor force declaring self-employed status is 27 percent-about double the Western European average. Empirical studies had found that uncovered jobs are a realistic option for low productivity workers (Torche and Wagner, 1997).

To be sure, previous literature showed that the marginal link between contributions and benefits in contributory old-age pensions affects the supply of hours to the labor market (Auerbach and Kotlikoff, 1987). However, that work is silent on the influence of noncontributory subsidies. Valdés-Prieto (2002, p. 241-57) shows how the availability of jobs exempt from the mandate to contribute allows workers to cap the implicit taxes imposed by a mandate, but is silent on the impact of non-contributory subsidies. Hubbard, Skinner and Zeldes (1995) argue that a steep or high withdrawal rate of subsidies to the old reduces the voluntary saving of the poor, but is silent on the impact on mandatory saving and on job choice. ${ }^{29}$ We find no previous focus on the link emphasized here.

\section{The baseline: stand-alone contributory subsidies}

Equations (5) are taken from a new model contributed by a companion paper (ValdesPrieto, 2008b). This model was not available during the reform process, but the verbal arguments in Beyer and Valdes-Prieto (2004) were essentially those reported here. This paper elaborates on that model and contributes figures 1 to 4 and equations (6) to (8).

Calendar time is grouped into the active and passive phases of life. The variables are:

\footnotetext{
${ }^{29}$ Although the empirical literature on the impact of tax incentives on voluntary saving finds modest elasticities for the poor (Attanasio and Browning, 1996), violent withdrawal of subsidies create unusually large implicit tax rates, allowing the effect on voluntary saving to be sizable.
} 
$y^{c}=$ gross earnings in the covered sector per unit time, in the active phase.

$t_{a}=$ other taxes on earnings applicable only to covered jobs in the active phase, such as contributions for health insurance, unemployment insurance, disability and housing, which have a low marginal benefit for the individual contributor.

$y^{e x}=$ earnings per unit time in self-employment and jobs that are exempt of or evade the mandate to contribute, in the active phase. $z^{e x}$ is the ratio $y^{e x} / y^{c}$, so $1-z^{e x}$ is the earnings differential against uncovered jobs.

$D=$ density, $\varepsilon[0,1]$. It is the proportion of the time in the active phase of life during which the individual contributes to some contributory pension system.

$e_{p}=$ earnings in old age, net of the fixed costs of old age, expressed as a proportion of $y^{c}$.

$\theta=$ contribution rate for old age, applicable only in covered jobs and uniform.

$R^{c}=$ the internal rate of return (in real terms) paid by the contributory pension system to each generation of participants. The earnings replacement rate is $\theta\left(1+R^{c}\right)$.

The following income identities include the contributory plans, but exclude independent saving in the financial market and the non-contributory subsidies.

$$
\begin{aligned}
& y_{a}(D) \equiv\left(y^{c} \cdot D\right) \cdot\left(1-\theta-t_{a}\right)+\left(z^{e x} \cdot y^{c}\right) \cdot(1-D) \\
& y_{p}(D) \equiv\left(y^{c} \cdot D\right) \cdot \theta \cdot\left(1+R^{c}\right)+e_{p} \cdot y^{c}
\end{aligned}
$$

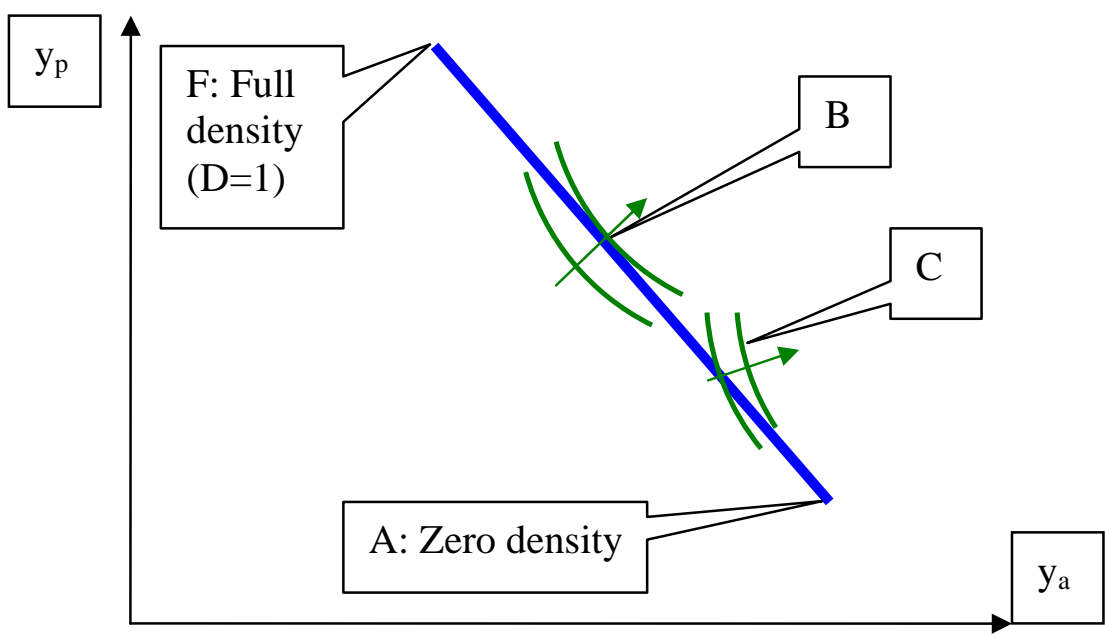

Figure 1: Income identities when uncovered jobs are available. (in the absence of noncontributory pensions and of independent saving)

Figure 1 presents equations (5) graphically, for the case where choosing an interior density is attractive $\left(0<D^{*}<1\right)$. Line AF is obtained by eliminating density $D$ from equations (5a) and (5b). The heavy line from A to F represents incomes achievable by varying $D$, the density of contribution, for members of the AFP system created in $1981^{30}$. The length of AF is proportional to the size of the contribution rate $\theta$. Figure 1 shows the case where the slope of AF is negative and the individual chooses an interior density of contribution. The

\footnotetext{
${ }^{30}$ For members of the old Chilean system, the figure differs in three ways: (a) there is a vesting requirement: $R^{c}=-1$ if $D<V_{\text {old }}$, where $V_{\text {old }}$ is the required density or years of contribution to avoid the loss of all contributions and interest; (b) there is an upper limit to benefits: $R^{c}=-1$ if $\theta\left(y^{c} D\right)\left(1+R^{c}\right)>\operatorname{Upper}$ Limit (set at about 3 times median earnings); (c) $R^{c}$ is set by legislation, so it differs from the one in the AFP system.
} 
companion paper shows that although preferences are defined over consumption, not income, these coincide in the case where an interior density is attractive.

Preferences may be of two classes. Some workers have standard preferences, like those in map B in figure 1. Other workers, whose preferences when young are represented by map C, suffer "unrealistic optimism" regarding old age (Weinstein 1980, Weinstein and Klein 1996, Puri and Robinson 2007). When young, these workers expect that their old age will be less expensive, net of earnings when old, than what it actually will be. This bias reduces the valuation of saving for old age. The presence of this group of workers provides a benevolent rationale for the mandate to contribute for old age.

\section{Impact on contribution density of non-contributory subsidies}

Up to the 2008 reform, there were three non-contributory subsidy programs for the old poor in Chile. The first two were described in section 2 and the third is described here. This section reviews them as an add-on to contributory pensions within a two-pillar regime.

First, consider elderly that do not participate in the AFP system, or, having chosen the old system, draw zero benefits because they don't meet a vesting requirement, $D>V_{\text {old }}$. They apply to the Assistance pension, whose benefit formula simplifies in this setting to ${ }^{31}$ :

$$
N C S_{\text {Case } 1}^{\text {Assis } \tan c e}(D)=\left\{\begin{array}{cc}
A & \text { if }\left(y^{c} D\right) \cdot \theta\left(1+R^{c}\right)<T \\
0 & \text { if not }
\end{array}\right.
$$

where $A$ is the size of the lifetime subsidy per month and $T$ is a threshold for the size of the contributory pension measured in $\$$ /month. This threshold is used to target the Assistance pension towards the poorest among the old. A higher contributory pension triggers the full loss of the subsidy (cliff withdrawal) when the Assistance Pension operates alone.

Figure 2 takes the perspective of an active worker who is deciding whether to take a covered job, which is bundled with a contributory pension, or to take uncovered jobs and save independently for old age. This figure adds the amount of the Assistance pension to the amount of the contributory pension. The impact on contribution density is obvious: for individuals that did not plan to save much for old age, it is optimal to reduce density of contribution, say from the one implicit in point B to the one implicit in point C.

\footnotetext{
${ }^{31}$ The Chilean Assistance pension has two additional thresholds, not shown in (6). One is based on the size of labor earnings in old age ( $0.5 \mathrm{MPGoal})$. The other is based on the size of per capita household income, which targets intrahousehold transfers (also at $0.5 \mathrm{MPGoal}$ ).
} 


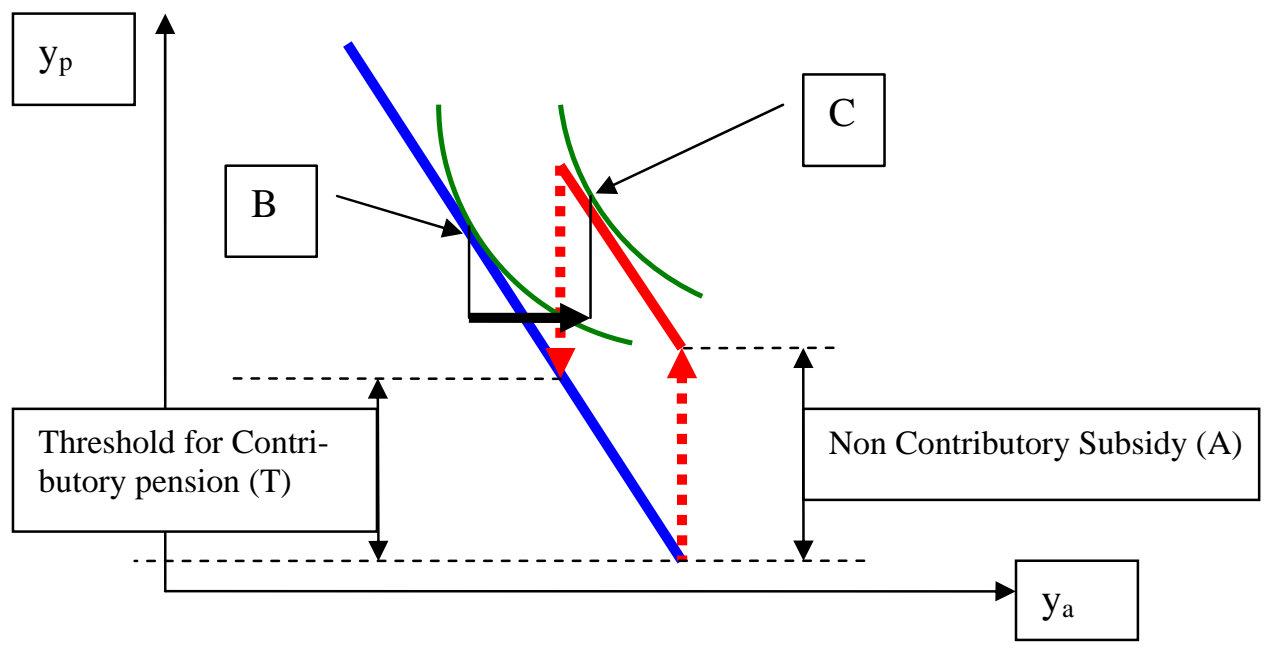

Figure 2: Contribution density falls when an Assistance Pension is introduced

Second, consider the minimum pension subsidy, created in 1952. Of course, it applies to members of the old system. Because of the transition started in 1981, as of 2005 most members of the old system had either started a pension, or were inactive and were waiting to complete the age requirement for a pension (van Rysselberghe, 2006). In 2005 only 2\% of employment contributed to the old system. For this reason, the minimum pension subsidy in the old system cannot explain the overall density observed currently in Chile, and this subsidy is not analyzed further. The minimum pension subsidy is important for the participants of the new AFP system, created in 1981. Its benefit formula is:

$$
\operatorname{NCS}_{M P}^{A F P \text { system }}(D)=\left\{\begin{array}{cc}
0 & \text { if } D<D_{V} \\
{\left[\text { MPGoal }-\left(y^{c} D\right) \cdot \theta\left(1+R^{c}\right)\right]} & \text { if }\left(y^{c} D\right) \text { is in-between } \\
0 & \text { if }\left(y^{c} D\right) \cdot \theta\left(1+R^{c}\right)>\text { MPGoal }
\end{array}\right.
$$

where $D_{V}$ is a 20-year vesting requirement, uniform across gender and jobs, and MPGoal is the statutory level of the minimum pension, adjusted annually by Congress. Participants with $D<D_{V}$ don't have access to the minimum pension subsidy, but may have access to the Assistance pension, and only for a limited period, as follows:

The Assistance pension is incompatible with any other pension. In the AFP system all participants obtain a contributory benefit, because they have property rights over contributions and its accumulated interest. ${ }^{32}$ The law specifies that when $D<D_{V}$, this contributory benefit is a limited-duration annuity. The amount of this annuity per period is equal to some level $L$, which in Chile is the statutory MPGoal. Recall that the threshold for the means-test is $T$. Since $T<L(T=0.5 M P G o a l$ and $L=M P G o a l)$, the Assistance pension is not available before exhaustion date.

The duration of this limited-duration annuity is given by the size of the individual accumulation at the start of the benefit. The expected duration of this annuity, as a fraction

\footnotetext{
${ }^{32}$ In the old system, participants with $D<D_{V}$ get zero benefits. They lose all their contributions and interest.
} 
of the old age phase, is $D\left[y^{c} \theta\left(1+R^{c}\right)\right] / L$, which is $<1$ because $L=M P G o a l$. This annuity is not a subsidy. It is self-financed.

The Assistance pension may obtain after exhaustion date. Two cases are possible, for average life expectancy ${ }^{33}$ :

a) The participant's other income, and his per-capita household income, are both low enough to make him eligible for the Assistance pension. In this case the subsidy is $A$ and the combined two-pillar benefit falls from $L$ to $A$ per period at exhaustion date. b) The participant's other income or average per-capita household income makes him ineligible. Here subsidies and contributory benefits are zero after exhaustion.

Summing up, for participants with $D<D_{V}$, the sum of subsidies received in old age is:

$$
N C S_{\text {AFP participants }}^{\text {Assit }}=\left\{\begin{array}{cc}
A \cdot\left(1-D \cdot \frac{y^{c} \theta\left(1+R^{c}\right)}{L}\right) & \text { if eligible for Assist. Pension } \\
0 & \text { if not }
\end{array}\right.
$$

where the expression in parenthesis is the proportion of the passive period after exhaustion of the limited-duration annuity. ${ }^{34}$

The focus is on the incentives for contribution density that are implicit in eq. (7) and (8). Both individuals are shown by figure 3. The worker that chooses $D<D_{V}$ and is eligible for the Assistance pension uses the first branch of equation (8), and is represented by preferences $\mathrm{H}$ and $\mathrm{G}$. The present value of receiving the Assistance pension is marked with the dash lines in figure 3 . If he chooses zero density, this present value is maximal at $A$. If he increases density, the exhaustion date increases, the budget point moves to the left of point $\mathrm{G}$ and the cumulative subsidy falls. According to Beyer and Valdes-Prieto (2004, p. 25-26), the subsidy withdrawal rate for this group in Chile is $61 \%$. For these preferences, the optimal density of contribution drops strongly.

The individual with $D>D_{V}$ has access to a Minimum Pension Subsidy. The amount of this subsidy is represented in figure 3 by the vertical line that ends at point $\mathrm{B}$. The horizontal level is given by the MPGoal. The limit to the right is given by the amount of resources contributed while complying with $D=D_{V}$. If the worker increases his contribution density further, the extra contributions are taken away at a $100 \%$ withdrawal rate. Contributing further than B is against the worker's welfare at the margin, because income in passive life is the same and income during active life is lower, because his contributions are larger. For the preferences marked E, the optimal density of contribution drops dramatically.

\footnotetext{
${ }^{33}$ The participant's funds must be insufficient to outlast life expectancy. If the funds are large enough to outlast life expectancy, the participant is not eligible for the Minimum Pension Subsidy to begin with.

${ }^{34}$ This reveals that the old Chilean design had a further defect: for individuals with $D<D_{V}$ the pension drops at exhaustion date from MPGoal, to either the Assistance pension $A$ or to zero, depending on eligibility. Since this drop is announced in advance to the participant, he might save in anticipation. However, if he is unable to save for any reason, consumption is not smoothed and the drop in benefits creates a further welfare loss. The drop also creates risk for participants because the exhaustion date is hard to predict, as it depends on the financial return of the pension fund. Valdes-Prieto (2006b) reported this inefficiency to the PAC.
} 
Summing up, research made in Chile over 2002-2004 by Beyer and Valdes-Prieto (2004) proved that the existing first-pillar designs induced a reduction in the average density of contribution. Part of self-employment among Chilean low-productivity workers could be explained by the poor design of these social programs. They create a "low contribution density trap" that severely punishes, through high subsidy withdrawal rates, those workers who increase their contribution density. Figures 2 and 3 show that these programs also increase total income when old, explaining the relatively low elderly poverty rate in Chile. In Chile, bad design was fully compatible with low poverty rates for the elderly.

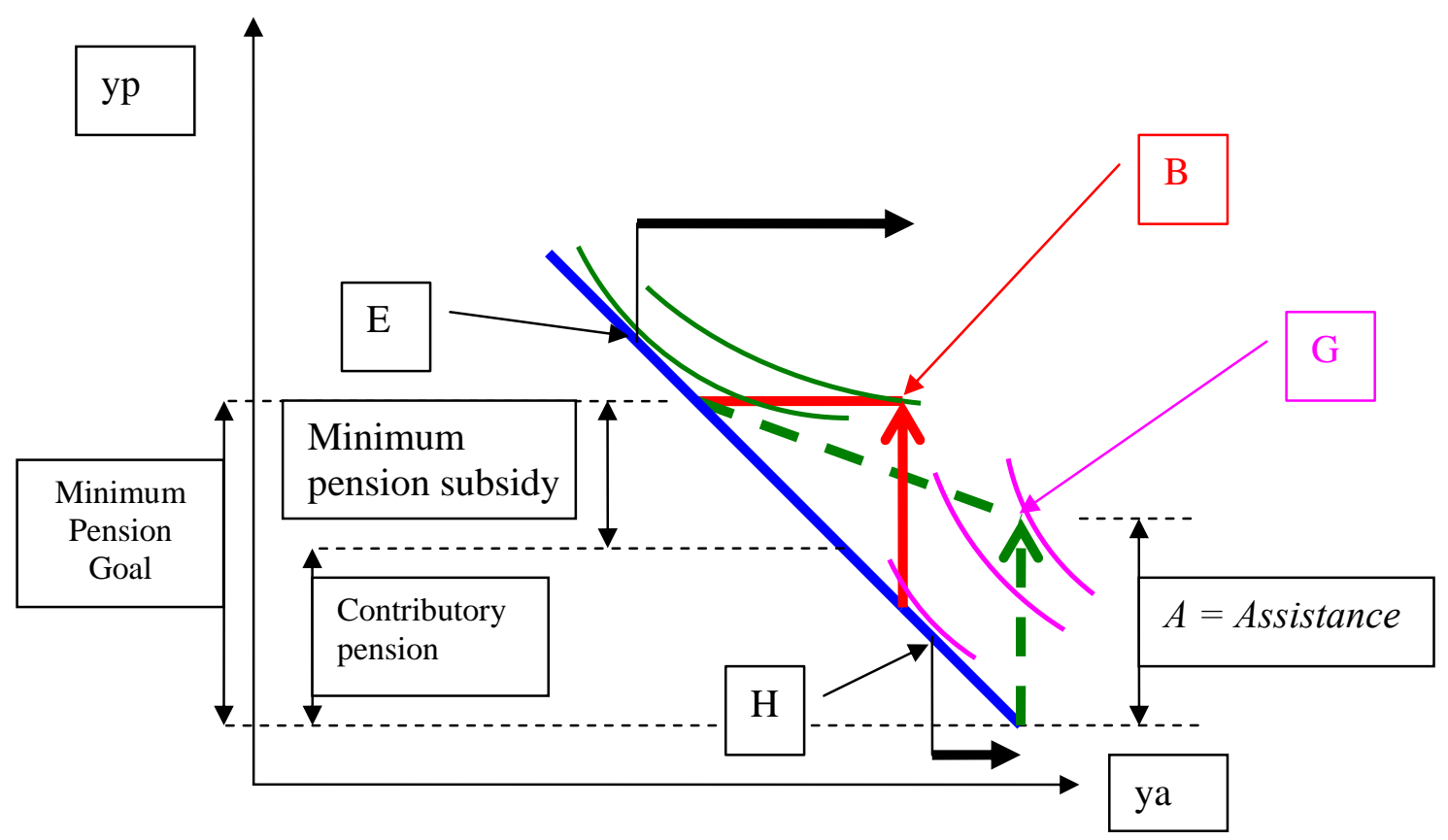

Figure 3: Income identities with a combination of a Minimum Pension Subsidy for the fully-funded system and an Assistance Pension.

This paper posits that these research findings were influential in the PAC's Report, and then on actual policy: these findings shifted the focus of the reform from the contributory to the non-contributory pillar. This is evident from the content of the reform.

This shift in focus did not go unopposed at the PAC. The opposing view was that the marginal effects (the subsidy withdrawal rates) that drive the analysis in this section are irrelevant, because most active participants are ignorant about the non-contributory subsidies they may obtain in old age, or fail to visualize them. Survey evidence for 2004 lends support to this view, since only 33\% of those surveyed declare that they know the amount of the Minimum Pension Goal (Bravo and Vásquez, 2007). However, other evidence shows that inability to visualize old age is not dominant in Chile. Independent financial saving and family support enable a significant share of senior citizens, nearly 24 percent, to be self-sustaining in old age, with no help from the contributory pension systems or from subsidies (GOCh, 2006 p. 6). Some 82 percent of the elderly above age 70 own their homes, demonstrating some planning capacity. Opinion studies in Chile led the 
PAC to conclude that "personal saving effort is legitimized widely as the main means of achieving (old age pensions with high replacement rates)” (PAC Report, p. 42).

\subsection{The design of the new Solidarity Pension}

After the November 2004 conference established the negative consequences for density of existing designs of non-contributory subsidies, the debate in 2005 and 2006 moved on to identify the best alternative policy. There were three competing designs, all of which shared the main feature of the Assistance pension of 1975: no vesting requirement $\left(D_{V}=0\right)$.

The Superintendence of AFP, employer associations and several bodies of the political opposition backed a design called "proportional minimum pension". In this design, the pension goal is not a constant, but is proportional to the number of months of contribution reported by the individual member. Talleres Bicentenario, an organization created by the opposition parties, endorsed it in its proposal $N^{\circ} 27$, section 2.1. The Superintendence also endorsed it: see Berstein et al (2005) p. 27 and Fajnzylber (2005). The employers' association (SOFOFA) also endorsed this design in its presentation to the PAC in 2006.

In contrast, Beyer and Valdes-Prieto (2004) proposed a benefit with concave shape, similar to the one of the Earned Income Tax Credit in the United States. It had two withdrawal rates rather than three. The third proposal was even simpler: a basic pension with a single constant withdrawal rate in response to contributory pensions and other income. This author proposed it in my presentation to the PAC and in the press (Valdés-Prieto, 2006b).

\section{The proportional minimum pension}

In a "proportional minimum pension", the minimum pension goal is not a fixed number, but grows with the number of years (or months, in the continuous time version) of contribution attained by each participant. Switzerland uses this design in its AHV system (first pillar) because the minimum pension is proportional to the number of years of contributions, if less than 44 years. However, it is not operative at the margin, because Switzerland also has a second minimum pension (the "pension supplement") whose goal has been set above the maximum pension from the $\mathrm{AHV}^{35}$. In this design, the subsidy is:

$$
P M P S^{i}=\operatorname{Max}\left[0 \quad ;\left(N^{i} / N_{R}\right) \cdot \operatorname{MPGoal}_{R}-C P^{i}\right]
$$

(\$/month)

where $P M P S^{i}$ is the amount of the monthly subsidy in old age for participant $i, N^{i}$ is the number of periods of contributions by participant $i$ (as the period is shortened, a continuous version obtains), $M P G o a l_{R}$ is the minimum pension goal for a reference number of periods of contribution, namely $N_{R}$, and $C P^{i}$ is the contributory pension built by participant $i$.

In my presentation to the PAC, I argued against a proportional minimum pension on the grounds of inefficiency (Valdés-Prieto 2006b). I modeled $C P^{i}$ for the admittedly restrictive

\footnotetext{
${ }^{35}$ I thank Professor Monika Butler for this information.
} 
case of a flat age-earnings profile with constant per-period density of contribution. In that case the pension is proportional to the future value function:

$$
C P^{i}=k^{i}(D) \cdot \frac{\left[\left(1+R^{c}\right)^{N i}-1\right]}{R^{c}}
$$

where $k^{i}$ is a proportionality constant that combines the annuity conversion factor and the time shape of declared earnings and density when active. $N^{i}$ and $R^{c}$ are as defined before.

Equation (10) highlights that $N^{i}$ affects the contributory pension exponentially. In contrast, the minimum pension goal grows linearly with $N^{i}$. The discrepancy between exponential and linear growth of $\mathrm{N}^{\mathrm{i}}$ has three implications for the size of the subsidy given by (9):

a) When the number of years of contribution is small, the minimum pension goal grows faster than the contributory pension and the subsidy grows with $N^{i}$. In this region there exists a marginal subsidy to increase the number of periods of contributions.

b) For a larger number of years of contribution, the opposite happens and the subsidy falls with $N^{i}$. In this range there is a marginal tax on participants that raise density. Moreover, this subsidy withdrawal rate varies continuously with $\left(k^{i}, N^{i}\right)$.

c) The amount of the subsidy has a different interior maximum for each value of $k^{i}$. The $N^{i}$ that maximizes the subsidy is larger for lower salaries.

According to simulations presented by Valdes-Prieto (2006b) to the PAC, the marginal subsidy can be as high as $350 \%$ for low values of $k^{i}$, but then falls to $-100 \%$, according to a curve that depends on the size of earnings. A 350\% subsidy rate is large enough to justify fraud. At the other extreme, a 100\% implicit tax rates on additional contributions preserves the undesirable incentive effects of the existing minimum pension subsidy.

Another problem of this design is its complexity, relative to a subsidy with few (one or two) withdrawal rates. Complexity raises the risk of planning errors for individuals. The proportional minimum pension is also vulnerable to underreporting of earnings. Consider the case of a fictitious job that is declared to be part-time and with the lowest possible wage, and whose only purpose is to allow persons outside the labor force to draw subsidies. This strategy is also effective in the case of the proportional minimum pension.

\section{Linear subsidies with constant withdrawal rates}

Now consider the competing designs: one is a subsidy with a single withdrawal rate. Valdés-Prieto (2002, pp. 57 and 70) represented this design with the following formula:

$$
N C S(D)^{S W}=\max [0 \quad ; \quad B P-\gamma \cdot C P(D)]
$$

where $C P(D)$ is the contributory pension financed by the participant, $B P$ is the basic pension or subsidy to those that never contributed to the second pillar, and $\gamma$ is the "withdrawal rate" of the subsidy, with $\gamma \varepsilon[0,1]$. If $M C P W S$ is defined as the maximum contributory pension with subsidy, the withdrawal rate is also $\gamma=B P / M C P W S$. 
Equation (11) includes a minimum pension subsidy and a universal flat pension as polar cases. If $\gamma=1$ (if $M C P W S=P B$ ), equation (7) is replicated. If $\gamma=0$ (if $M C P W S=\infty$ ), a flat universal pension (paid to all) is obtained, such as those used in Denmark and New Zealand. The Australian "age pension" is similar but with a taper for $C P(D)>T>>$. However, the family of linear subsidies described by equation (11) also includes cases where $\gamma$ may be in-between.

Finland introduced in 1957 a noncontributory subsidy that effectively has a single withdrawal rate. In the Finnish design, the withdrawal rate is $0 \%$ for a very small initial range (up to the equivalent to $2 \%$ of the average wage), and then in a second and main tranche the withdrawal rate is $50 \%$, applied to the amount of the contributory pension that exceeds the small initial amount (Antolin et al 2001, figures 5 and note 11). During the debates of Chilean reform process Valdes-Prieto advertised the fact that Nordic countries used designs taken from the "single withdrawal rate" family.

Inserting equation (11) into the model in the companion paper shows that when density rises, income in old age increases in proportion to $(1-\gamma)$. Each $\$ 1$ of additional contribution is used by the State to withdraw its own subsidy by $\$ \gamma$ cents, leaving $\$(1-\gamma)$ cents to the participant to increase his total pre-tax pension (combining contributory and noncontributory pensions). Figure 4 shows this graphically.

In figure 4, the subsidies are the vertical distance between the solid line, AF, and the heavy dotted line A'C. The basic subsidy BP is paid to individuals who choose zero density $(\mathrm{D}=0)$. The maximum contributory pension that receives a subsidy, the $M C P W S$, is the contributory pension at point $\mathrm{C}$, which demands a significant density. The slope of AC is the net return of the combined two-pillar system. The companion paper shows that this slope is the net return of the contributory part, $\left(\left(1+R^{c}\right) \cdot \theta /\left[\theta+t_{a}-\left(1-z^{e x}\right)\right]\right)$ times $(1-\gamma)$.

Figure 4 shows that a noncontributory subsidy with this design reduces the chosen density, from the one associated to point $\mathrm{D}$ to E. Therefore, a single withdrawal subsidy also crowds out contributory pensions. Valdes-Prieto (2002) argued that the reduction in density is smaller than the reduction in the standard designs, because $\gamma$ is smaller. The gain from a small withdrawal rate is that it alleviates crowding-out of the contributory system in the AC segment. However, crowding-out is not eliminated. 


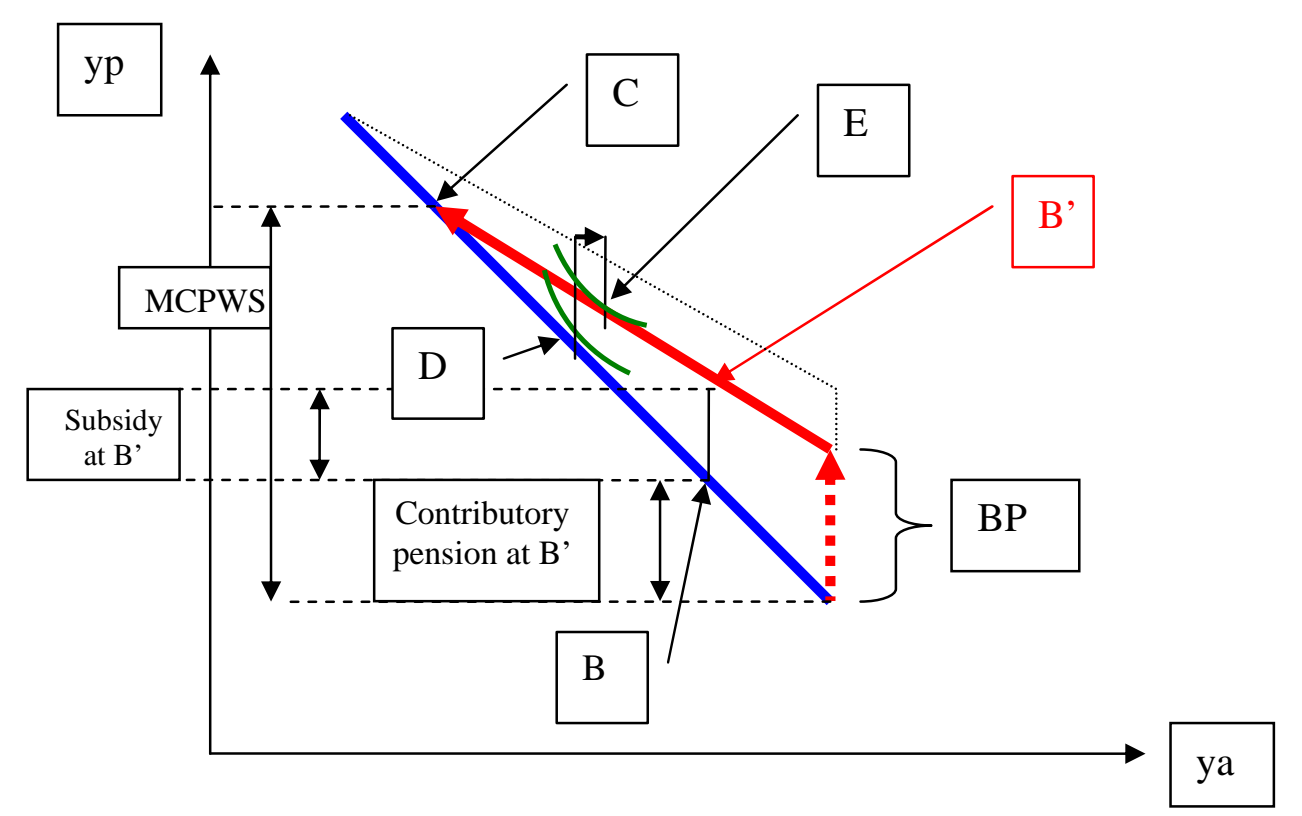

Figure 4: Income identities for a subsidy with a small withdrawal rate

Other shapes are possible. The new Swedish “minimum pension supplement”, in force since 2003, has two withdrawal rates that create a convex shape: the noncontributory subsidy is withdrawn first at the much higher rate of $100 \%$ in the range with very low densities. This initial range is substantial $(\gamma=1$ if $C P(D)<1.26$ base amounts, and the size of the basic subsidy is 2.13 base amounts, or 77,532 SKR per year in 1998). In the second tranche, a second withdrawal rate of $48 \%$ applies $(\gamma=0.48$ when CP(D) is between 1.26 and 3.07 base amounts, Scherman 1999). The Norwegian reform of 2005, to be applied from 2010, also relies on two withdrawal rates in a convex shape: $100 \%$ for the initial range and $60 \%$ for the second tranche (Pedersen, 2005).

The proposal by Beyer and Valdes-Prieto (2004) also has two withdrawal rates, but following a concave shape, as in the Earned Income Tax Credit applied in the United States. The two proposed withdrawal rates were $0 \%$ for the initial amount and $40 \%$ subsequently.

How should one choose between two convex rates and two concave rates? Valdés-Prieto (2002, p. 67-71) provided an answer by applying the results of the simulations by Slemrod et al (1994), which draws on optimal income tax theory. That paper finds that the convex design provides a better combination of efficiency and equity. This argues against the concave proposal by Beyer and Valdés-Prieto (2004).

How choose between the "single rate" Finnish design and the "two-rate" design? A critical aspect of the two-rate scheme is the high level of the first rate. Valdés-Prieto (2006b) argued to the PAC that the priority should be to avoid high withdrawal rates, for efficiency reasons, and also for equity reasons because the high rate would apply to the poor. 
These views were not unopposed. Opponents to the single withdrawal rate family of subsidies in the Chilean debate compared it with a minimum pension subsidy that has the same fiscal cost. To simplify, let us assume also that $D_{V}=0$ in the minimum pension subsidy. The equal fiscal cost condition implies that the $M C P W S$ is greater than the Minimum Pension Goal. Then, the single withdrawal rate subsidy is paid to workers that have a contributory pension larger than the Minimum Pension Goal. These workers become the subjects of an implicit tax at rate $\gamma$ in covered jobs, which they would not have suffered under a standard minimum pension subsidy. Thus, this group reduces its density of contribution (Juan-Andrés Fontaine, 2006).

The answer to this criticism was that the low-productivity participants reduce their density of contribution to a greater extent with the minimum pension subsidy. Since this group is poorer, their utility increases have higher social value than the utility losses of higher income individuals. This is one of the messages of the optimal income tax literature (Mirrlees, 1971). Thus, public finance theory recommends that the "low density trap" be mitigated by reducing $\gamma$, but not to zero (Diamond 1998, Valdés-Prieto 2002, p. 67-71). ${ }^{36}$

Dante Poblete's Master's thesis (2005, Universidad Católica de Chile) offered additional findings, which Valdes-Prieto (2006b) presented to the PAC. His first finding is that the extreme with $\gamma=0$ never maximizes social welfare, because the fiscal cost of the program is large and exacerbates tax distortions. Therefore, a universal flat benefit is suboptimal, even if fiscally feasible. Second, small reductions in $\gamma$ from an initial level of 1 are irrelevant, because participants remain in corner solutions. Thus, if improvements in density are desired, the cut to the withdrawal rate has to be substantial. Third, Poblete (2005) finds that the optimal social value for the withdrawal rate $\gamma$ is approximately 20 percent, within his simplified model.

As this debate got more technical, more members of the PAC became confused. These complex arguments appeared inconclusive to most members. In this author's view, horizontal inequities settled this debate.

\subsection{Horizontal inequities in first-pillar programs}

Already the CASEN 1994 survey revealed that 60 percent of the recipients of the Assistance pension for the elderly did not belong to the poorest 20 percent of households ranked by per capita household income, and 10 percent of the recipients belonged to the wealthiest 40 percent of households ranked by per capita family income. ${ }^{37}$ Using a survey of the perception of the beneficiaries themselves (EBEN), it was found that 42 percent of the recipients of the Assistance pension for the elderly did not think that the subsidy had been granted to them because they were poor, but because of other factors. The EBEN Survey found a large number of people who met the requirements for receiving the Assistance pension for old age but did not, accounting for 17 percent of those actually

\footnotetext{
${ }^{36}$ The workers affected by these incentives receive a modest fraction of the national income, so their savings do not have an impact on national saving.

${ }^{37}$ Source: Focus (1998), in particular pp. 2-19, 3-5, 3-7, 3-9, 3-25, and 3-35. The author's access to this report was expressly authorized by the Ministry of Planning and Cooperation.
} 
receiving it. Among the potential recipients who are not receiving the Assistance pension for old age, 82 percent are in fact poor. Some of these problems have been alleviated since 1994.

With respect to inequities in the minimum pension subsidy, the finding reported in ValdésPrieto (2002, p. 60) is revealing: the number of women in the richest quintile by family per capita income that received the minimum pension subsidy was 3.7 times larger than the number of women recipients in the poorest quintile, according to CASEN 1996.

Moreover, these inequities are also sources of risk for the individual, when seen ex-ante. A related point is that recent social changes that have increased the proportion of femaleheaded households with few children, suggests that intra-family transfers (including care) are likely to fall in coming decades. Therefore horizontal inequities in non-contributory pensions are less likely to be compensated by intra-family transfers. This is an argument for reducing inequities, not for raising the average level of non-contributory subsidies.

However, these inequity arguments failed to attract political support for reform for at least 13 years. Successive elected governments failed to become interested in reforming noncontributory subsidies. One reason is that the Ministry of Finance avoids comparisons that suggest increases in expenditure (to compensate the losers). Another is that existing system suited the politicians, because it allowed them to grant favors in the allocation of the Assistance pensions, in exchange for votes, or at least allowed their local political allies in the district to do so.

This scenario changed in 2006, possibly in response to the new prominence of gender issues brought about by the election of a female President. Inequities against female fruitpickers that specialize on seasonal work attracted politicians' interest. Beyer and ValdesPrieto (2004) had contributed to this by showing that many of inequities against fruit harvesters could be explained by the high vesting requirement of the minimum pension subsidy. Subsequently, the political drive for reform in the center-left parties became substantial. However, the Ministry of Finance didn't share this emphasis, as suggested by the absence of the inequity topic in the presentation made by the Deputy Director of the Budget at an important ILO seminar in April 2004 (Arenas, 2004).

Horizontal inequities also decided the debate between a proportional minimum pension and a linear subsidy, because in his presentation to the PAC, Valdes-Prieto (2006b) proposed a vivid example that showed how the proportional minimum pension fails the test of horizontal inequity. His illustration was:

Case A: A seasonally employed woman works intensively on the fruit harvest for 3 months a year, earning a wage of CLP\$ 200,000 a month in exchange for 12-hour workdays sweating in the sun. It is assumed that she works seasonally from the ages of 20 to 39. Then at age 60 she meets the legal age for starting a contributory pension, which may last until she dies at age 82. She postpones consumption of her contributions for 41 years on average.

Case B: Another (middle or upper class) woman works as a part-time secretary for a wage of CLP\$ 132,665 a month, 5 hour a day, 12 months a year, between the ages of 40 and 59 . Her contributory pension may last 
from age 60 until she dies at age 82. She postpones consumption of her contributions for only 21 years on average.

This illustration selects the numbers so that the accumulation at age 60 (pension age) is the same for both women, for a real interest rate of 5 percent a year. Therefore, both women self-finance the same contributory pension (CLP\$ 31,105 per month if annuities yield 4 percent real a year). Since the accumulation as of pension age is a measure of the lifetime saving effort, both should get the same subsidy on horizontal equity grounds.

However, the seasonal fruit-picker has only five years (60 months) of contribution. If the minimum pension goal (MPGoal ${ }_{R}$ ) is CLP $\$ 90,000$ for a reference period of $N_{R}=20$ years, (close to Chilean reality as of 2006), the proportional minimum pension goal for her is $(5 / 20)$ CLP $\$ 90,000=$ CLP\$ 22,500. Since this is smaller than her contributory pension of CLP\$31,105/month, her subsidy is zero! ${ }^{38}$

In contrast, the middle class secretary has 20 years of contributions. Her proportional minimum pension goal is (20/20) CLP\$90,000. Given her contributory pension of CLP\$ $31,105 /$ month, her subsidy is CLP\$ 58,895 per month, which is substantial! ${ }^{39}$

The inequity is obvious. According to private information provided by several members, this vivid example was decisive to induce the PAC to favor the linear subsidy.

The economics behind this example is that a proportional minimum pension creates horizontal inequities because it implicitly defines saving effort in terms of the number of years (or months) of contribution $N^{i}$. This ignores differences in the amount of each contribution and in the timing of the contributions. Because of this, a proportional minimum pension cannot be optimal.

\section{The copper bonanza and the pension reform}

The 2008 Chilean reform ocurred in between a fiscal bonanza, which explains part of its outcome and also reduces the replicability of the experience. About $34 \%$ of the world's production of non-recycled copper takes place in Chile. International prices for copper began to rise in late 2003, doubled in 2004 and grew even higher until the first half of 2008. prices dropped after the financial crisis started by the demise of Lehman Bro. A major share of the rent created by this price increase was captured by the Chilean State, both through income taxes on foreign-owned copper mines, and through the profits of Codelco, a large state-owned copper company.

This rent came on top of solid fiscal finances, firmly established since 1978. Fiscal stability was further enhanced since 2000 by the adoption of a "fiscal rule", whereby the

\footnotetext{
${ }^{38}$ The seasonal fruit-picker can collect the Assistance pension in the Chilean case, but it cannot be accessed until her accumulation is exhausted. Moreover, the amount of the Assistance pension is half the CLP\$90,000.

${ }^{39}$ This subsidy lasts about 22 years on average, counted from age 60 . The present value of this subsidy as of age 60, discounted at a real interest rate of 4 percent is CLP\$ 10.2 million. Comparing with her accumulation at age 60, the average rate of subsidy for her is 190 percent.
} 
government commits to achieve a goal for the budget, measured on an accrued basis and most important, after cleaning for the effects of cycles in the price of copper by using a 10year-ahead projected average price, rather than the one-year-ahead projected price. Cycles in other tax revenue are also cleaned. From 2004 to December 2007, the adherence of the government to this rule created a cumulative budget surplus of about $20 \%$ of GDP. A large portion of it was used to create a sovereign fund invested internationally. ${ }^{40}$

This 10-year-ahead average price goes much further into the future than futures contracts. Being free from arbitrage, the 10-year average fluctuates less than future market prices. Nevertheless, the 10-year projected average rose substantially in 2003-2006. This allowed the government to expand expenditure lavishly in a number of programs, including education vouchers, while still saving the majority of the revenue increase.

The copper bonanza put the Ministry of Finance under political pressure to spend more, possibly by increasing benefits throughout the welfare network, which comprises about 20 subsidy programs plus health and education subsidies. Other possible uses of funds were reductions in tax rates and higher expenditure in crime control. In Chile, increases in welfare benefits have traditionally been the most effective vote-winners. One reason to increase spending in subsidies for the old poor was the buildup of a substantial stock of research about a pension reform, reported in section 4 . Another was the political needs of the 2005 presidential campaign, presented in section 3. Last, but not least, was overrepresentation of the old in the electoral registers ${ }^{41}$.

A prolonged copper boom can force any Chilean Minister of Finance to abandon fiscal prudence. For most Chilean economists, abandoning the fiscal rule would have had two detrimental effects: (i) higher risk for the poor, because in its absence, the contraction of welfare expenditure in periods of low copper prices would be more pronounced; and (ii) higher vulnerability to the Dutch disease, brought about by spells of high copper prices. In several episodes of Chilean economic history, the Dutch disease has killed export-led growth and employment. Anticipating this, the Ministry of Finance developed defensive strategies to limit the generosity of politicians during the pension reform.

\subsection{Defensive strategies by the Ministry of Finance}

The first defensive strategy used by the Budget Office was to raise the myth that a "fiscal crisis is coming” in the pension area.

The "fiscal crisis" story could not be applied directly to the 1981 reform, because its transition cost, borne by taxpayers, had peaked in 2004-5 and was bound to fall thereafter. This fall creates scope to raise expenditure over the coming 20 years, in the range of 2.0

\footnotetext{
${ }^{40}$ Another force that helped improve the fiscal balance was the conservative level of the budget goal chosen in 2000-07: a surplus of 1.0\% of GDP. In the 2008 fiscal year this conservative bias was reduced marginally, by cutting the budget surplus goal from $1.0 \%$ to $0.5 \%$ of GDP. This change had a modest impact.

${ }^{41}$ Beyer (2005) reports that $22 \%$ of those registered were aged 55 or more as of early 2005.
} 
percent of GDP. This fact precludeded blaming the 1981 reform for the limits to spending that the Ministry needed to defend the fiscal rule in $2007 .{ }^{42}$

The Ministry of Finance decided to transfer the "fiscal crisis is coming" myth to another policy decision made in 1981: the extension of the minimum pension subsidy created in 1952, to participants that chose to join the new AFP system. The target is surprising, since minimum pension subsidies were extended to all pension regimes in 1963, so it was natural that the creation of any new regime would come with an extension of coverage to the new regime's participants. In the end, this myth could not be sustained, leaving the Ministry of Finance unprotected from the political demands to increase pension subsidies.

The events unfolded as follows. As of 2005, the cash fiscal cost of this extension of the minimum pension subsidy was less than $0.1 \%$ of GDP. However, since 1999 the Budget Office had issued projections where this expenditure would increase at a very fast pace over the next three decades. Officials asserted publicly that this trend posed "serious fiscal risks" that demanded restraint. Implicitly, the military government was blamed. The Budget Office went as far as to propose the creation of a sovereign fund to support that looming fiscal expense, the "Pension Reserve Fund". In 2005 Congress approved its creation, together with a much larger sovereign stabilization fund.

However, the high growth rate in minimum pension subsidies for AFP participants is transitory, so no serious fiscal risk was present. It arises only because most participants that in 1981 chose to switch to the AFP system were younger than 45. The mechanical implication is that the expenditure in minimum pension subsidies for that group would be unusually small during the first two decades, to be followed by a fast increase for the following two decades, and by stability thereafter. Simultaneously, fiscal expenditure in minimum pension subsidies for participants in the old system falls significantly, as they pass away. The combined cost of the minimum pension subsidy for both groups of participants (AFP and old system) remains more or less constant over the coming decades, as was first shown by Valdes-Prieto (2006c). This prediction was confirmed by van Rysselberghe (2006), who used a more precise methodology based on sampling and on the details of the benefit formulae of the old system (see Table 3).

Table 3: Fiscal cost of Chilean non-contributory subsidies without the 2008 reform (\% of current GDP)

\begin{tabular}{|l|c|c|c|}
\hline $\begin{array}{l}\text { Minimum pension subsidies for participants in } \\
\text { fully funded (AFP) plan }\end{array}$ & Year 2007 & Year 2015 & Year 2025 \\
\hline $\begin{array}{l}\text { Minimum pension subsidies for participants in } \\
\text { old pay-as-you-go plans }\end{array}$ & $0.10 \%$ & $0.10 \%$ & $0.30 \%$ \\
\hline Assistance pensions & $0.58 \%$ & $0.47 \%$ & $0.34 \%$ \\
\hline TOTAL & $0.40 \%$ & $0.40 \%$ & $0.60 \%$ \\
\hline \multicolumn{2}{|l|}{$1.08 \%$} & $0.97 \%$ & $1.24 \%$ \\
\hline
\end{tabular}

\footnotetext{
${ }^{42}$ Still, leading officials in the Ministry of Finance tried to present a picture of fiscal weakness where the 1981 pension reform was the major culprit. See a description of those efforts in Valdes-Prieto (2006c).
} 
Source: van Rysselberghe (2006). Takes into account wage indexation of benefit parameters. The impact of the ageing process is included.

Table 3 shows that in the absence of the 2008 reform, the overall fiscal cost of noncontributory subsidies would have remained constant below $1.25 \%$ of GDP. Table 3 left no room for the myth that a "fiscal crisis is coming" in the area of non-contributory pensions. The prickling of this myth also left the "Pension Reserve Fund" without justification.

Unfortunately, officials in the Ministry of Finance continued pushing this myth as of early 2006, as demonstrated by the presentation made by the Budget Office to the PAC in late March 2006. The PAC did not believe this story, in part because a paper circulated in May to its members revealed the flaws in the Budget Office's numbers (Valdés-Prieto, 2006c).

By 2007, the Ministry of Finance had been reduced to argue that the looming costs of the minimum pension subsidy for AFP participants had "ceased to be contingent" and had now "materialized" in the fiscal cost of the new Solidarity Pension, whose extra expenditure now would be supported by the Pension Reserve Fund. This ignores that the extra expenditure required by the new Solidarity Pension was created by the 2008 pension reform itself, which is a policy not envisaged in the 1981 extension of the minimum pension subsidy to participants in the new contributory system.

By insisting in an untenable defensive strategy the Ministry was weakened, and politicians were able to get a large increase in subsidies. This failure explains why the 2008 reform raised the level of the basic subsidy for a pensioned couple rose to $77 \%$ of the autonomous income (market wage) of a couple in the 40th percentile of the income distribution. The former level of the Assistance pension was 48\% of the same benchmark, as of March 2006.

Table 4: Pension increase in relation to market wages (both nominal)

\begin{tabular}{|l|c|c|c|c|}
\hline \multicolumn{1}{|c|}{ Month } & $\begin{array}{c}\text { Basic subsidy } \\
\text { for an } \\
\text { individual (CLP) }\end{array}$ & $\begin{array}{c}\text { Basic subsidy for } \\
\text { elderly couple } \\
\text { (A) (CLP) }\end{array}$ & $\begin{array}{c}\text { Autonomous income for a } \\
\text { couple in percentile 40 according } \\
\text { to CASEN 2006 (B) (CLP) }\end{array}$ & $\begin{array}{c}\text { (A)/(B) } \\
\text { Ratio }\end{array}$ \\
\hline January 2006 & $\$ 40,000$ & $\$ 80,000$ & $\$ 167,316$ & 0.478 \\
\hline May 2006 & $\$ 44,000$ & $\$ 88,000$ & $\$ 167,316$ & 0.526 \\
\hline July 2008 & $\$ 60,000$ & $\$ 120,000$ & $\$ 181,036$ (est.) & 0.663 \\
\hline July 2009 & $\$ 75,000$ & $\$ 150,000$ & $\$ 195,519$ (est.) & 0.767 \\
\hline
\end{tabular}

Sources: (Valdes-Prieto 2007b). Percentile 40 from www.mideplan.cl, adjusted by wage inflation of $8.2 \%$ in the 12 months ended in September 2007. Wage inflation from July 2008 to July 2009 is projected at 8\%.

A basic pension at $77 \%$ of the market wage for a couple in the $40^{\text {th }}$ percentile is likely to be too large on several counts. First, this large benefit increase created a large age-based asymmetry in the Chilean welfare network. As shown by Table 4, the non-elderly are left behind, since they must work all day to attain a level of consumption similar to the retired elderly. Given the age distribution of poverty (Table 1), this asymmetry should be expected to trigger demands to distribute the copper surplus to other age groups as well. 
An indication that this may indeed be happening is the debate on the "ethical salary" which erupted in mid 2007. Senior politicians from all parties and some bishops proposed to restore the ratio stressed in Table 4 by raising the monthly minimum salary. Unfortunately, this necessitates an increase to a level above median (market) earnings. The proposed "ethical salary" of CLP\$250,000 was 25\% above median market earnings, so its implementation would have caused mass unemployment.

The Ministry also had to concede measures that maximized the electoral impact of the increase in non-contributory subsidies. For example, the transition schedule of the reform increases the basic pension in two steps, the first a few months before municipal elections (October 2008), and the second just before parliamentary and presidential elections (December 2009) (Table 4). ${ }^{43}$ Opposition politicians responded rationally, by requesting that both increases be brought forward to May 2008. This response may have diluted to some extent the electoral impact of this large increase in subsidies.

The Ministry of Finance was also forced to ditch reasonable proposals made by the PAC, when conceding to politicians during the negotiations in 2006 and 2007. One was the creation of an autonomous institution to raise pension ages in response to increases in life expectancy. Another was ending the current gender bias in pension ages, which favors middle class women with a pension age of 60, rather than 65 for men.

\subsection{The fiscal cost of the new Solidarity Pension}

The report to Congress in which the Ministry of Finance described the fiscal impact of the 2008 reform has only one page devoted to the Solidarity pension. The only figure reported by the Ministry of Finance was the incremental fiscal cost caused by this new design, and in only four selected years: 2008, 2009, 2010 and 2025. In September 2007, ten months after Congress began discussion of the project, the Ministry of Finance issued a second financial report, which repeated the figures given in the first projection and added figures for the incremental fiscal cost in years 2011 to 2017. Years 2018 to 2024 remained omitted.

No sensitivity analysis about standard assumptions, such as the impact of different pension indexation rules, was provided to Congress. The costs of the first pillars programs in the absence of reform was not reported to Congress. For example, the fiscal cost of the minimum pension subsidy for members of the old system was not reported (Table 3 was not distributed to members of Parliament) ${ }^{44}$. Thus, the level of fiscal expenditure on the

\footnotetext{
${ }^{43}$ The Government went further: it proposed that the distribution of the increments to non-contributory pensions (the PBS and APS) will begin in July 2008, just before the municipal election of 2008, but only if the new law was approved and published by March 2008. However, if Congress delays approval until June 2008, the benefits would not reach constituets until after the municipal election, to their displeasure. By this means, the Government prevented serious deliberation about this law in Parliament.

${ }^{44}$ The Ministry of Finance has only reported this cost within a single global figure, where it is lumped together with: (a) expenditure in contributory pension in the old system; (b) with non-contributory pensions not related to old age, such as those for family members of people who died or disappeared during the Pinochet dictatorship, for individuals who declared themselves tortured and for individuals who were fired from public sector jobs during the Pinochet government. This lack of transparency may be explained by political reasons. Valdes-Prieto (2006b) and Van Rysselberghe (2006) have provided estimates of the fiscal cost of the minimum pension subsidy in the old system.
} 
new solidarity pension could not be debated. ${ }^{45}$ Most important, the Ministry’s cost projection model was secret, so its assumptions could not be verified independently.

According to the reported projection, the annual incremental fiscal cost projected for years 2017 (when the originally proposed transition would end) and 2025 (the end of the projection horizon) are 771 and 1,336 billion pesos of 2007, respectively. ${ }^{46}$ To put these figures into perspective, they can be divided by real GDP at 2003 prices plus CPI inflation, ${ }^{47}$ and GDP can be assumed to grow at $4.0 \%$ real per year. Incremental fiscal costs in 2017 and 2025 would be $0.74 \%$ and $0.94 \%$ of current GDP, respectively. Adding these figures to the fiscal costs of the continuation of the current system, which were estimated by van Rysselberghe for 2025 (Table 3), the total combined fiscal costs for 2025 would be $2.18 \%$ of current GDP. ${ }^{48}$

The actual fiscal impact is likely to be higher. The fiscal cost of the final agreement of December 2007, which raised the MCPWS parameter from CLP\$200,000 to CLP\$ 255,000 (by 27.5\%), is not included in the figures just quoted. The 2008 law indexes the new basic subsidy to prices, not to wages, and the projection model accepts this at face value (see GOCh 2008b). However, when the history of legislated increases over the last five decades is taken into account, the implicit indexation has been to wages, not prices. Since price indexation contradicts the political equilibrium, some future government is likely to attempt to win votes by switching to wage indexation, either with ad-hoc legislation or with an explicit rule. The fiscal impact of this adjustment can be large. If real market wages increase by $2 \%$ per year, the cumulative growth in real wages would be $42 \%$ over 2007 2025. For example, if a return to wage indexation occurs in 2010, the incremental fiscal costs for 2025 would be $1.26 \%$ of GDP rather than $0.84 \%$ of GDP. The official report of December 2008 fails to make these standard adjustments and to provide sensitivity analysis.

\section{The final stages of reform and the transition clauses ${ }^{49}$}

\subsection{The extraordinary 10\% real increase of April 2006}

\footnotetext{
${ }^{45}$ Only much later, in October 2008, the Budget Office provided a first cursory description of its projection model (GOCh 2008a, section III.3.3 in p. 70-78). But the reform was approved 10 months before, in January 16, 2008. In late December 2008 the Budget Office issued another report with some detail (GOCh 2008b), but it still reports figures rather than tables, and does not report econometric equations. The projection model has not been checked by independent experts and in essence, remains secret.

${ }^{46}$ Source: Informe Financiero Sustitutivo No 89-2007, of September 13, 2007, available in www.dipres.cl

${ }^{47}$ Thios procedure eliminates the impact of high copper prices on nominal GDP. This estimate takes real GDP for 2007 at constant 2003 prices, and adjusts by CPI inflation from 2003 to 2007 (averages for each year), which was 12.41\%. Real GDP for 2007 at 2006 prices is estimated as real GDP for 2006 at 2003 prices $(59,588)$ plus $5 \%$, which is 70,332 billion pesos.

${ }^{48}$ This figure is larger than the cost of Brazil's rural pension, which was about $1.88 \%$ of GDP in 2002. The difference is due in part to tighter targeting in Chile: Brazil's rural pension is almost universal, while the coverage of all three Chilean subsidies was about $42 \%$ of the elderly in the absence of reform and may rise to $60 \%$ with the reform.

${ }^{49}$ Chamber of Deputies (2006), Valparaíso, January 16. Later published as law No 20.255.
} 
In January 2006, before the new government took office, the amount of the Assistance pension for a single person received its customary adjustment for inflation and reached CLP\$40,000 per month (for beneficiaries aged less than 70; larger amounts for older beneficiaries). In the same month, the Minimum Pension Goal for a couple (if the pensioner dies, his widow obtains a survivor's annuity at $60 \%$ of the Minimum Pension Goal) was adjusted to CLP\$79,867 (again, for beneficiaries aged less than 70; larger for older beneficiaries).

In April 2006, the Government applied an extraordinary 10 percent increase, in real terms, to the Assistance pension and the Minimum Pension Goal. This increase was discussed in Congress in parallel to the hearings held by the PAC regarding the longer term design. This approach may be explained as another defensive strategy by the Ministry of Finance, which attempted to vent the political pressure to raise benefits, and free the PAC to design a transition path from this adjusted initial level. If so, the strategy backfired.

\subsection{Self-contradiction in the PAC's Report}

The PAC did not reach a consensus about the appropriate level for the new Solidarity Pension. On July 11, 2006, the PAC Report was unveiled. On the crucial matter of the amount of the basic subsidy, the Report was self-contradictory:

a) One section proposes to "introduce the new subsidy gradually, setting the initial value of the basic subsidy at the current value of the Assistance pension" (p. 112), and "no immediate effects should be expected from this proposal" (p. 197). A newspaper interviewed some of the members of the Advisory Council and reported that the initial value would be the current Assistance pension. ${ }^{50}$ Five members of the PAC informed to this author, in personal communication, that they understood that this was the agreement; but

b) Other sections in the Report propose the opposite, specifically that the initial value of the basic subsidy would be CLP\$75,000. Another says this amount "would be 84\% of the minimum salary net of contributions, way above the replacement rate that $O E C D$ countries offer to low income workers, which is 73\%" (p. 119 and 114).

This shows that, when faced with the absence of an agreement, the coordinator of the PAC, Mr. Mario Marcel, chose to write a self-contradictory report. Many of the commission's members were not shown the complete report before signing it. Indeed, if the process had been transparent, the Report may have not been signed by some of the members.

When the Report was unveiled to the press, the coordinator took sides and emphasized the high figure for the basic subsidy. This was immediately followed by statements from leaders of the Socialist Party, who endorsed the proposed amount of CLP\$75,000 and ignored p. 112 and 197 of the report. The coordinator is also a member of the Socialist Party. The Ministry of Finance was unable to maneuver, so the Government also endorsed the report's proposal of CLP\$75,000 in the project of law it presented to Congress.

\footnotetext{
${ }^{50}$ La Segunda, July 11, 2006, p. 22, Santiago.
} 


\subsection{The transition path}

Table 5 reports the new transition schedule agreed in December 13, 2007, between the government and the Senate's leaders. It differs from the schedule proposed initially in that the maximum contributory pension with subsidy $(M C P W S)$ is raised from the beginning of the transition, rather than leaving all the increase to the next government (from 2010).

This adjustment brings forward the fiscal cost, but also provides political stability to the new design by highlighting the number of beneficiaries. To see this, consider a situation in which the number of beneficiaries is not highlighted, and only the size of the basic pension is emphasized. In this case, the 2008 reform would have been vulnerable to new legislation in 2009 or 2010 to raise the basic pension further, and to keep the fiscal cost constant the $M C P W S$ would have been reduced. However, that legislation would have undone the improvement in marginal incentives (Valdes-Prieto 2007b).

Table 5: Transition schedule agreed December 13, 2008. (nominal CLP; after July 2012 all figures are indexed by prices)

\begin{tabular}{|c|c|c|c|c|}
\hline $\begin{array}{c}\text { Year } \\
\text { (starting in } \\
\text { July) }\end{array}$ & $\begin{array}{c}\text { Basic Pension } \\
\text { (CLP\$/month) } \\
\pi=\text { CPI inflation }\end{array}$ & $\begin{array}{c}\text { MCPWS } \\
\text { (CLP\$/month) }\end{array}$ & $\begin{array}{c}\gamma \text { (estimated) } \\
\text { (= PBS/ MCPWS })\end{array}$ & $\begin{array}{c}\text { Excluded } \\
\text { percentiles by } \\
\text { household income }\end{array}$ \\
\hline 2008 & 60,000 & 70,000 & 85.7 percent & Top 60 percent \\
\hline 2009 & 75,000 & 120,000 & 62.5 percent & Top 55 percent \\
\hline 2010 & 75,000 & 150,000 & 50.0 percent & Top 50 percent \\
\hline 2011 & $\begin{array}{c}75,000 \\
\left(1+\pi_{2010: 07-2011: 06}\right)\end{array}$ & 200,000 & $\begin{array}{c}37.5 \% \\
\left(1+\pi_{2010: 07-2011: 06}\right)\end{array}$ & Top 45 percent \\
\hline 2012 and + & $\begin{array}{c}75,000 \\
\left(1+\pi_{2010: 07-2012: 06}\right)\end{array}$ & 255,000 & $\begin{array}{c}29.4 \% \\
\left(1+\pi_{2010: 07-2012: 06}\right)\end{array}$ & Top 40 percent \\
\hline
\end{tabular}

Source: text of the law approved by Congress in January 16, 2008. The portion of the transition that applies during to the administration that follows Bachelet's is in italics. The last line is the legislated steady state.

Some entries in Table 5 depend on future inflation within a specific period -denoted $\pi_{2010: 07-2011: 06}$ and $\pi_{2010: 07-2012: 06}$. The reason is that indexation to prices applies to MCPWS only from July 2012 onwards, but it applies to the basic pension amount from July 2010 onwards. If cumulative CPI inflation between July 2010 and July 2012 is 8\%, then the withdrawal rate will attain a value of 32\% from 2012 onwards.

The last column of Table 5 shows that the 2008 pension reform is a direct heir to the policy established in Chile in 1975, by which benefits are also withdrawn in response to the beneficiary's household income. Across Chilean society, these exclusions are considered equitable. This is not the consensus in the Nordic countries, none of which takes into account intra-household transfers and capital consumption as a type of income that can reduce the subsidy. 
The Solidarity pension created in 2008 innovates somewhat by redefining the threshold at which the beneficiary's household income becomes large enough to trigger the loss of the benefit. In the Assistance pension, this threshold was 50\% of the Minimum Pension Goal, a nominal amount adjusted by law every year. In the new Solidarity pension, the threshold is a given percentile in the distribution of per capita household income. The specific percentiles are reported in Table 5. Being above the given percentile triggers cliff withdrawal of the subsidy, with negative consequences for individual risk, horizontal equity and incentives.

\section{New problems created by the 2008 reform}

This section identifies four new problems created by the 2008 reform.

\subsection{New desincentives regarding contribution density}

The increase in non-contributory subsidies, relative to median (market) earnings (Table 4), has an income effect. Since this extra subsidy is paid only in old age, it creates a new incentive to reduce the density of contribution. This is shown in figure 4, where the light dotted line shows the new income set after expanding the size of the basic subsidy BP, while keeping the withdrawal rate constant. In this new income set the participant chooses a smaller density of contribution.

In addition, a number of medium-productivity workers, who would have faced an implicit tax on contributions of $0 \%$ without the large increase, are now affected by the implicit tax on contributions of $32 \%$.

These effects undermine the efficiency argument for reform: that existing non-contributory subsidies crowded out contributory pensions, by inducing participants to cut density of contribution. For this reason, the coverage rate of contributory pensions $C C P$ should not be expected to improve by 2025. Of course, other clauses of the reform, not discussed in this paper, may improve coverage by 2025.

\subsection{An unimplementable definition of household}

In the new Solidarity pension, the subsidy is withdrawn if the household's per-capita income exceeds a threshold given by a percentile in the national distribution of per capita household income. This depends on a definition of household being the same as the definition used in the survey used to calculate the distribution of household income.

However, the new law introduced a new definition of household, that is incompatible with the definition used by the survey which is the source of the data used to rank households by average income per capita. Specifically, the new law defines household on the basis of blood ties, while the CASEN survey defines household on the basis of sharing cooking and shelter. Although a transition clause allows the use of the existing survey definitions until 2010, at that date this new definition may cause a major operational crisis. Avoiding such a disruption does not depend only on taking a new household survey that includes bloodline 
questions, but also on re-surveying all beneficieries to establish the percentile where each one falls in the new national distribution of per capita household income. The costs to the old poor of an operational crisis like this one may surpass any gains from improved benefit design. For this reason, it is likely that this aspect of the reform will be overturned.

\subsection{Preservation of cliff withdrawal of benefits}

The cliff withdrawal of benefits according to household income was a major problem of the Assistance pension. It remains a major problem in the new Solidarity pension. As shown by Table 5, the household whose per capita income is slightly above the threshold percentile loses all benefits. This preserves a large source of individual risk for the poor, which is due to the absence of a gradual withdrawal in this dimension. Another consequence is a large incentive to manipulate answers to the personal survey (Ficha de Protección Social, FPS), allowing inequities and abuses.

The PAC debated proposals to insert a smaller withdrawal rate in this dimension. However, the majority of the PAC rejected them. One group opposed means tests on principle. Another group did not care because it believed that the affected set of people is very small (those that have a contributory pension below the MCPWS (CLP\$ 255,000) and also belongs to an income percentile above the $60^{\text {th }}$ ). However, recent calculations based on the CASEN survey show that the affected people are about 160,000 or $10 \%$ of the elderly ${ }^{51}$.

\subsection{Discrimination in the transition clauses to favor of participants in the old system}

The reform introduces two new inequities in the transition clauses. The first occurred in April 2006, when the extraordinary 10\% increase to the minimum pension goal took place. Some contributory pensions above the new minimum pension goal were subsidized for the first time, with an amount equal to $10 \%$ of their amount. However, participants in the new fully funded system were excluded from this extra subsidy.

This discrimination was not presented openly to Congress. Most members of parliament did not notice this inequity and the others didn't tell. When this fact was made public in June, politicians of all parties chose to ignore the issue (Valdes-Prieto, 2006a).

The second inequity is contained in the transitional provisions. Pensioners preserve their current subsidies, but are allowed to (are presumed to request a) switch to the new subsidies as soon as the new subsidies become larger. This implies that the new subsidy substitutes the current subsidies at a $100 \%$ at the margin. However, this principle is ignored when some current subsidies are redefined not to be subsidies. The next equations explain this and follow the notation of section 4 . The combined two-pillar pension is:

$$
\text { Pension }^{\text {Transition }}=\left(y^{c} D\right) \cdot \theta\left(1+R^{c}\right)+\max \left[N C S^{M P} \quad ; N C S^{\text {transition }}\right] \quad \text {, where }
$$

\footnotetext{
${ }^{51}$ I thank Rodrigo Cerda for these figures. It is the number of pensioners above age 65 that belong at the two deciles around the threshold where cliff withdrawal occurs, and whose pension is below CLP\$255,000 (the $M C P W S$ ). The deciles are defined on the basis of per-capita household income before transfers.
} 


$$
N C S^{\text {Transition }}=\left\{\begin{array}{c}
B P-\gamma \cdot\left\{\left(y^{c} D\right) \cdot \theta\left(1+R^{c}\right)+N C S^{M P}\right\} \text { in the old system } \\
B P-\gamma \cdot\left\{\left(y^{c} D\right) \cdot \theta\left(1+R^{c}\right)+0\right\} \quad \text { in the new system }
\end{array}\right.
$$

Note that the term $N C S^{M P}$ appears twice for old system participants: the new subsidy is calculated with the formula in eq. (13), which treats $N C S^{M P}$ as a contributory pension, despite the fact that it is a subsidy. In contrast, participants in the new system face full substitution: they get either the existing minimum pension subsidy, as calculated with (7), or the new benefit, in which case the $N C S^{M P}$ term is excluded from equation (13).

This inequity was included in the legislation without alerting Congress. However, it was revealed in the press in October 2007, when Congress still had time to take corrective action (Valdes-Prieto, 2007a). Congress preferred a speedy approval that would allow the benefits to be paid out before the Municipal elections of October 2008. This response may also be explained by the Ministry of Finance's inability to devise workable methods to reverse this inequity. This horizontal inequity may bring additional spending pressure in the future.

\section{Final remarks}

This reform shows that the political stability of a contributory system (second pillar) can be influenced by the effectiveness of non-contributory subsidies (first pillar). When the State does not provide a universal mandate, the contributory system pays inadequate pensions relative to earnings due to low density, and thus fails to alleviate unrealistic optimism. Naturally, public opinion is likely to believe that a low density of contribution is a defect of the contributory system.

In Chile, the argument that low density is a result of an underdeveloped labor market was considered an excuse, since accepting it does not solve the problem and helps preserve an unsatisfactory status quo. In a situation of low density and low pensions, it may be tempting to introduce pay-as-you-go finance to grant large supplements to all contributory pensions, to be paid by future generations. This was the path taken by Chile in 1952, and by many other countries then and now. This difficult scenario was changed by the argument that inadequate design of non-contributory subsidies is the culprit of low contribution density.

What happens when the size of the new subsidy becomes large? Although the effect on density may be lost, large subsidies also raise total pensions relative to earnings, and thus the consequences of low density for elderly consumption are alleviated. Since high total pensions protect the contributory system from accussations of inadequacy, it is fair to assert that the policy stability of the AFP system was increased by the 2008 pension reform (Valdes-Prieto, 2008).

\section{References}

Antolin, P., H. Oxley and W. Suyker (2001), "How Will Ageing Affect Finland?", OECD Economics Department Working Papers, No. 295, OECD Publishing. 
Arenas, A. (2004) “The pensions system in Chile: main future challenges”, International Labor Office (Publisher) El sistema de pensiones en Chile en el contexto mundial y de América Latina: evaluación y desafios, presentations at international seminar in Santiago, April 22-23, Santiago, p. 106-113 (in Spanish).

Attanasio, O. and M. Browning (1996) "Consumption over the life cycle and over the business cycle", American Economic Review 85 (5), p. 1118-37.

Auerbach, A. and L. Kotlikoff (1987) Dynamic Fiscal Policy, Cambridge University Press.

Barr, N. and P. Diamond (2008) Reforming Pensions: Principles and Policy Choices, Oxford University Press.

Berstein, S., G. Larraín and F. Pino (2004) "Coverage, density and pensions in Chile: a projection 20 years ahead”, first presented at international seminar organized by Centro de Estudios Públicos and Superintendence of AFP, November 11-12 2004, Santiago; See also "Chilean Pension Reform: Coverage Facts and Policy Alternatives”, Economía, Volume 6, Number 2, Spring 2006, pp. 227-279.

Beyer, H. (2005) “Old age pensions in the political arena”, signed column (op-ed) in El Mercurio newspaper, Sunday February 20, page A2, Santiago (in Spanish).

Beyer, H. and S. Valdés-Prieto (2004) “Proposal to increase the density of contribution”, report for national Office for Women (SERNAM), March, Santiago; later version presented at international seminar organized by Centro de Estudios Públicos and Superintendence of AFP, November 11-12, Santiago (in Spanish), available in www.cepchile.cl

Bravo, D. and J. Vásquez (2007) “Conocimiento del Sistema de Pensiones de Chile”, Boletín Previsional N 2 (June), Bulletin at the Centro de Microdatos, www.proteccionsocial.cl/english/documentosBoletin2006.htm

Chamber of Deputies (2008) Pension Reform Law; Oficio N 7,259 from the Chamber of Deputies to the President of the Republic of Chile, Valparaíso, January 16.

Fajnzylber, E. (2005) "Pensions for all: analysis of alternatives to extend coverage of the Chilean pension system”, En foco Document Expansiva No 65 (in Spanish), www.expansiva.cl

Focus (1998) “Pensiones Asistenciales”, Part 2 in Proyecto Evaluación de la Política de Subsidios Sociales Priorizados vía Ficha CAS2, Final Report for the Ministry for Planning and Cooperation , June, Santiago, Chile (in Spanish).

Government of Chile (2006) Message of the Government's pension reform proposal to Congress, Mensaje $\mathrm{N}^{\circ}$ 558-354, December 19, (in Spanish), available in www.bcn.cl

Government of Chile (2007) Informe de Finanzas Públicas 2008 (Report on Public Finances for the 2008 budget), issued October 2007 by the Ministry of Finance, www.dipres.cl . See section 5.1.

Government of Chile (2008a) Informe de Finanzas Públicas 2009 (Report on Public Finances for the 2009 budget), issued October 6, 2008 by the Ministry of Finance, www.dipres.cl. See section .

Government of Chile (2008b) La Reforma Previsional Chilena: Proyecciones Fiscales 2009-2025, December, Budget Office, Ministry of Finance, www,dipres.cl.

Hubbard, G., J. Skinner and S. Zeldes (1995), “Precautionary saving and social insurance”, Journal of Political Economy, 103 (2), April.

Kotlikoff, L. (1997) “Its high time to privatize” Brookings Review 15 , No. 3 (Summer): 1622. See also Kotlikoff, L. and J. Sachs (1998) “The Personal Security System: A Framework for Reforming Social Security” in Federeal Reserve Bank of St. Louis Review, March/April, p. 11-13. 
Litchfield, J. (2002) "Poverty and inequality in Chile 1987-2000”, in Chile: Household risk management and social protection, Human Development Sector Unit, LAC, World Bank, Washington D.C. August. Available in http://wbln0018.worldbank.org/LAC/lacinfoclient.nsf/6f1c77f445edaa6585256746007718fe/37e5a286f8eef0358 5256ea6007cdb80/\$FILE/JLitchfield_pov\&ineq_fin.pdf

Mirrlees, J. (1971), “An exploration in the theory of optimum income taxation”, Review of Economic Studies, 38, p. 175-208.

Molina, S., A. Donoso, A. Llona, S. Baeza and M. Kast (1974) “Mapa de la Extrema Pobreza en Chile”, Working Paper N N $^{\circ}$, Instituto de Economia, Catholic University of Chile, 3.57 MB www.economia.puc.cl

PAC (2006) Report of the Presidential Advisory Council for Pension Reform, Volumes I and II, edited by Secretaría de Comunicaciones, Ministerio Secretaría General de Gobierno, Santiago, July (in Spanish).

Pedersen, A.W. (2005) “Two technical choices with critical implications: Issues in Scandinavian pension reform”. NOVA-Norwegian Social Research Working paper 6/05, Oslo.

Poblete, Dante (2005) “Grado de Focalización Óptimo de las Pensiones No Contributivas en el Tercer Mundo”, Thesis in Economics, Instituto de Economía, Universidad Católica de Chile, www.economia.puc.cl

Puri, M. and D.T. Robinson (2007) “Optimism and economic choice” Journal of Financial Economics, Volume 86, Issue 1, October 2007, Pages 71-99.

Sinn, H.W. (1999) "Why a Funded System is Needed and why it is not Needed," International Tax and Public Finance, Volume 7, Numbers 4-5, August 2000 , pp. 389-410(22).

Slemrod, J., S. Yitzhaki, J. Mayshar and M. Lundholm (1994) "The optimal two-bracket linear income tax", Journal of Public Economics 53, 2, p. 269-290.

Titelman, D. and Uthoff, A. (2005), “The Role of Insurance in Social Protection in Latin America”, International Social Security Review, Vol. 58, 2-3/2005, Oxford (UK) and Malden (USA), p. 43-68.

Torche, A. and G. Wagner (1998) "Social Security: individual valuation of a mandated benefit ", Cuadernos de Economía, No 103, p. 363-390, (in Spanish) available in www.economia.puc.cl.

Valdés-Prieto, S. (2002) Pension policies and pensions markets: a university textbook for Latin America, Ediciones Universidad Católica, 930 pages, Santiago (in Spanish). Available in www.edicionesuc.cl.

Valdés-Prieto, S. (2004) “An evaluation of recent pension policies in Chile”, in International Labor Office (publisher), El sistema de pensiones en Chile en el contexto mundial y de América latina: evaluación y desafios, presentations at international seminar in Santiago, April 22-23, p. 106-113 (in Spanish).

Valdés-Prieto, S. (2006a) “There is a big injustice”, interview in El Mercurio newspaper, Sunday June 11, page B9, Santiago (in Spanish), available in www.economia.puc.cl "Faculty” button.

Valdés-Prieto, S. (2006b) "Presentations to the Presidential Advisory Council on Pension Reform”, April 11 and 19, Santiago, English version available at my webpage, at www.economia.puc.cl "Faculty" button.

Valdés-Prieto, S. (2006c) "Fiscal policy and expenditure in minimum pension subsidies and Assistance pensions”, Estudios Públicos No 103, p. 43-110 (in Spanish), available in www.cepchile.cl

Valdés-Prieto, S. (2007a) “Grave discrimination in social security”, signed column (op-ed) in El Mercurio newspaper, Sunday October 20, p. A2, Santiago (in Spanish), available in www.economia.puc.cl "Faculty” button. 
Valdés-Prieto, S. (2007b) “Solidarity pension: advantages, defects and proposals”, Temas de la Agenda Pública series No 13, December, Santiago de Chile, (in Spanish), www.puc.cl/agendapublica/

Valdes-Prieto, S. (2008a) “The creator of the solidarity pension speaks”, signed column (op ed) in $E l$ Mercurio newspaper, Sunday January 20, p. B3.

Valdes-Prieto, S. (2008b) “Contribution density and social insurance”, mimeo Instituto de Economía, P. Univsidad Católica de Chile.

van Rysselberghe, C. (2006) "Estimation and projection of expenditure in minimum pension subsidies in the old Chilean pension system: 2006-2025”, Thesis for a Master’s Degree in Economics, Economics Institute, Universidad Católica de Chile, Santiago (in Spanish).

Wagner, G. (1991) “Social security and the guaranteed minimum pension”, Estudios de Economía, 18 (1), journal available in http://estudiosdeeconomia.cl, Santiago (in Spanish).

Weinstein, N.D. (1980) “Unrealistic optimism about future life events”, Journal of Personality and Social Psychology, Vo. 39, N 5, p. 806-820.

Weinstein, N.D. and W.M. Klein (1996) “Unrealistic Optimism: Present and Future”, Journal Of Social And Clinical Psychology, Guilford Press.

World Bank (2000) The Korean Pension System at a Crossroads, Report N²004-KO, Washington D.C.

\section{Appendix:}

\section{Coverage of contributory pensions: Projection for 2025 without reform}

The first projection of benefit coverage rates for AFP pensions (contributory) for the long run was made by Wagner (1991), using simulations for a steady state. He found that many female participants would not meet the 20-year contribution requirement, and would not obtain a Minimum Pension Subsidy. Only the poor would obtain an Assistance pension.

Beyer and Valdes-Prieto (2004, March) used the PRIESO survey taken in 2000 by Truman Packard from the World Bank, to make a steady state projection in Table A.1.

Table A.1: Share of participants projected to attain three different situations (among participants of the AFP system alone)

\begin{tabular}{|c|c|c|c|}
\hline & Men & Women & All \\
\hline $\begin{array}{c}\text { Self-finances the MP Goal or more } \\
\text { with contributions }\end{array}$ & $64.8 \%$ & $30.8 \%$ & $50.5 \%$ \\
\hline $\begin{array}{c}\text { Attains the 20-year contribution requirement for a } \\
\text { Minimum Pension subsidy }\end{array}$ & $16.4 \%$ & $28.6 \%$ & $21.5 \%$ \\
\hline $\begin{array}{c}\text { Does not attain the 20-year contribution requirement and } \\
\text { does not self-finance a MP goal. Candidate for Assistance }\end{array}$ & $18.8 \%$ & $40.6 \%$ & $28.0 \%$ \\
\hline
\end{tabular}

Source: First two columns from Table 5 in Beyer and Valdés-Prieto (2004) and from their data in the text in p. 50-52, all based on the PRIESO survey. The last column is calculated here from the other two, using the fact that $42.1 \%$ of participants in the AFP system were female as of December 2000 (year of the PRIESO survey)..

The last column of Table A.1 says that $72.0 \%$ of participants in the AFP system would attain a contributory coverage of sufficient size. Within this group, 50.5 percentage points do not require fiscal support in old age, as reported in the main text. 
Since 2001 the Chilean government invested in building an individual panel data base. The first HLSS survey was taken in 2002. ${ }^{52}$ In April 2004, the Deputy Director of the Budget confirmed the results of Table A.1 with the first results of the HLSS survey. He stated that "the sum of recipients of Assistance pensions and beneficiaries of pensions equal to or less than the minimum pension (goal) will be about 50 percent of those insured under the AFP system” (Arenas, 2004, p. 105).

Officials at the Superintendence of AFP did proprietary econometric work on the HLSS data. They estimated probit equations for the probability of contributing, and earnings equations, with the purpose of simulating account balances, densities of contribution and coverage for the next 20 years. This study and its projections for 2025 was first presented publicly in an international seminar organized jointly by Centro de Estudios Públicos and the Superintendence of AFP, which took place in Santiago, November 11-12, 2004 (Berstein, Larraín and Pino, 2004). This seminar was organized joiuntly by this author and Mrs. S. Berstein, then Chief if Studies at the Superintendence of AFP. This study modifies the results of Table A.1, in the way shown in Table A.2.

Table A.2: Share of participants projected to attain three different situations (among participants of the AFP system alone)

\begin{tabular}{|c|c|c|}
\hline Survey/sample & $\begin{array}{c}\text { PRIESO in 2000, used } \\
\text { by Beyer and Valdes- } \\
\text { Prieto, March 2004) }\end{array}$ & $\begin{array}{c}\text { HLSS in 2002, projected to } \\
\text { 2025 by Berstein, Larraín and } \\
\text { Pino (November 2004) }\end{array}$ \\
\hline $\begin{array}{c}\text { Self-finances the MP Goal or more } \\
\text { with contributions }\end{array}$ & $50.5 \%$ & $10 \%$ \\
\hline $\begin{array}{c}\text { Attains the 20-year contribution requirement } \\
\text { for a MP subsidy }\end{array}$ & $21.5 \%$ & $40 \%$ \\
\hline $\begin{array}{c}\text { Does not attain the 20-year contribution } \\
\text { requirement and does not self-finance a MP } \\
\text { goal. Candidate for Assistance }\end{array}$ & $28.0 \%$ & \\
\hline
\end{tabular}

Source of second column: Table 2 and figure 12 in Berstein et al. (2004) in the (realistic) scenario where politicians index the minimum pension goal to market wages. ${ }^{53,54}$

Next, this Appendix shows how to transform these ratios into a figure for coverage of contributory pensions $(C C P)$.

Let us begin by repeating the definition of $C C P$, in equation (1) of the text:

$$
C C P_{t} \equiv \frac{C_{t}^{\text {SpecialEP }} \text { net }}{\text { All the elderly }}+\frac{C_{t}^{\text {Old System }}}{\text { All the elderly }}+\frac{C_{t}^{A F P}}{\text { All the elderly }}
$$

Define $\alpha_{\mathrm{t}}=$ number of contributory pensions from the old system plus special employer plans, divided by all the elderly, as of date t. Thus,

\footnotetext{
${ }^{52}$ HLSS is an acronym for Historias Laborales y de Seguridad Social. The HLSS was based on the PRIESO survey, but it was not made available to non-government (independent) researchers and from the members of the Presidential Advisory Commission on Pension Reform, until late 2006 when the Presidential Advisory Commission had already issued its Report (July 2006).

53 The abstract of that paper reports an even more radical cut to 5\%, but this corresponds to a scenario with price indexation of the minimum pension goal. That scenario contradicts Chilean history since 1952, where the minimum pension goal has been indexed to wages, not prices, for long periods.

${ }^{54}$ Other projections by the Superintendence of AFP are consistent with these numbers: $46 \%$ of the annual flow of new pensioners under the AFP system between 2020 and 2025 will have a pension below the minimum pension goal and no access to the minimum pension subsidy (GOCh, 2006).
} 


$$
\left(C_{t}^{\text {SpecialEP }} \text { net }+C_{t}^{\text {Old System }}\right)=\alpha_{t} \cdot(\text { All the elderly })
$$

Let us define $\beta_{\mathrm{t}}$ as the number of non-participants in any contributory system divided by all the elderly, as of date t. This implies that:

$$
[\text { Non }- \text { Participants }]=\beta_{t} \cdot(\text { All the elderly })
$$

Since in the old system and in the special employer plans no elderly can at the same time be a participant and be uncovered (the AFP system is the only one where both situations are compatible), it follows that:

(A.4) All the elderly $\equiv\left(C_{t}^{\text {SpecialEP }} n e t+C_{t}^{\text {Old System }}+C_{t}^{A F P}\right)+N C_{t}^{\text {Participants AFP }}+$ Non-Participants

Eliminating Non-Participants from equations (A.3) and (A.4):

(A.5) All the elderly $\equiv \frac{1}{1-\beta_{t}} \cdot\left[\left(C_{t}^{\text {SpecialEP }} n e t+C_{t}^{\text {Old System }}+C_{t}^{A F P}\right)+N C_{t}^{\text {Participants } A F P}\right]$

Define $\mathrm{R}_{\mathrm{t}}$ as the ratio between participants on the AFP system that self finance low pensions and do not comply with the vesting requirement, and the other participants. $R_{t} \equiv\left(N C_{t}^{\text {Participants } A F P} / C_{t}^{A F P}\right)$. Using (A.2) again in (A.5) yields:

(A.6) All the elderly $\equiv \frac{1}{1-\beta_{t}} \cdot\left[\left(\alpha_{t} \cdot(\right.\right.$ All the elderly $\left.\left.)+C_{t}^{A F P}\right)+R_{t} \cdot C_{t}^{A F P}\right]$, and

$$
\left(\frac{C_{t}^{A F P}}{\text { All the elderly }}\right) \equiv \frac{1-\beta_{t}-\alpha_{t}}{1+R_{t}}
$$

Adding back the first and second ratios using (A.2), it follows that

$$
C C P_{t} \equiv \frac{1-\beta_{t}+\alpha_{t} \cdot R_{t}}{1+R_{t}} \quad \text {, for any value of } Q_{t} \text {, as reported in the main text. }
$$

Finally, this Appendix offers data for calibration of parameters for sensitivity analysis. Consider $\alpha_{\mathfrak{t}}$, the number of contributory pensions from the old system plus special employer plans, divided by all the elderly. Since the police and the armed forces are permanent institutions, it is natural to assume that in the absence of reform, the second component of this ratio will remain constant over time. The value of the second ratio as of 2025 depends on how fast does the old system dies out. The sum of both ratios for 2004 was 38\%. Other projections for the old system show that it will die out rather slowly, by about 2035 (van Rysselberghe 2006). A alue for $\alpha_{t}$ in 2025 is 0.15 implies that the old system's coverage ratio falls to a third of the current level, if the Especial Employer Plan's ratio remains at 0.06. Because of uncertainty, symmetric changes around this central value are considered in the sensitivity analysis reported in the main text.

Consider $\beta_{\mathrm{t}}$, the number of non-participants in any contributory system divided by all the elderly, as of date t. The PRIESO survey reports for year 2000 the percentage of the elderly that has never had a covered job for even one month, neither in the AFP nor in the old systems, i.e. the percentage of "non-participants". This ratio is $12.5 \%$ for men and $38.2 \%$ for women. According to the national population projections, the proportion of women in the elderly population (aged 65 and more) was $58.33 \%$ in 2000 , and it is projected to be $55.86 \%$ in 
2025 (the absolute numbers rise a lot, because of ageing)..$^{55}$ Thus, the weighted average proportion of nonparticipants for 2000 was $27.5 \%$. This figure is likely to fall for several reasons. First, the labor force participation of women of ages 15 or more rose from $30 \%$ in 1988 to $40.8 \%$ in 2008 , and this trend is likely to continue. Second, introduction of the AFP system will be completed only by about 2025, increasing the number of individuals who contribute to it at least once in their lifetime. Third, economic development should increase the attraction of covered jobs. Fourth, other policies such as the new mandate to the "formal" independent to contribute, will be in force by 2025. For this reason, sensitivity analysis is done for values for $\beta_{2025}$ of $22 \%$ and $17 \%$.

The data on $R_{t}$ is obtained from Table A.2. The Beyer et al (2004) study yields a ratio of $0.28 / 0.72=0.389$, while the Berstein et al (2004) study yields a ratio of $0.40 / 0.60=0.667$. How to choose? The Berstein et al (2004) paper suffers from two shortcomings. First, the specification of the earnings equation excludes improvements in labor productivity that come from higher total factor productivity and from a rising capital/labor ratio. In their in their specification, experience is the only factor that is allowed to improve labor productivity, contradicting most available evidence. The resulting bias under-estimates the proportion of each cohort that self-finances a minimum pension, and reduces projected coverage for 2025. Second, the estimated age-earnings profile is almost flat. This contradicts all the available evidence for Chile and abroad. A flat profile under-estimates the proportion of each cohort that self-finances a minimum pension, and this reduces projected coverage artificially. These objections were presented to the Presidential Advisory Commission (Valdes-Prieto, 2006b), but the Commission's Report did not register them and did not acknowledge their implications.

The Berstein et al (2004) projection has the advantage of being based on micro panel data from the 2002 survey, which is matched with administrative data from the individual account records at the AFP system. However, this survey data was withheld from independent researchers until late 2006, until after the PAC's Report was issued, and the administrative data has not been released. The unavailability of the data helps explain the fact that, to date, the specification and the matching procedure in the Berstein el al paper has not been subject to independent confirmation ${ }^{56}$.

\footnotetext{
${ }^{55}$ http://www.ine.cl/canales/chile_estadistico/demografia_y_vitales/proyecciones/DatPais/Copia\%20de\%20Sa ITPusuariosOK1.xls\#'T2'!A1

${ }^{56}$ Without prejudice towards the valuable contribution made by Berstein et al, an independent evaluation is justified for another reason as well: two of the three co-authors were political appointees: G. Larraín was Superintendent of AFP in 2003-2006, and from July 2007 to date has been Superintendent of Securities and Insurance. S. Berstein was Chief of Studies at the Superintendence of AFP in 2003-2006 and has been the Superintendent of AFP since 2006. F. Pino was junior Economist at the Superintendence of AFP.
} 


\section{CESifo Working Paper Series}

for full list see www.cesifo-group.org/wp

(address: Poschingerstr. 5, 81679 Munich, Germany, office@cesifo.de)

2457 Andreas Knabe and Steffen Rätzel, Scarring or Scaring? The Psychological Impact of Past Unemployment and Future Unemployment Risk, November 2008

2458 John Whalley and Sean Walsh, Bringing the Copenhagen Global Climate Change Negotiations to Conclusion, November 2008

2459 Daniel Mejía, The War on Illegal Drugs in Producer and Consumer Countries: A Simple Analytical Framework, November 2008

2460 Carola Frydman, Learning from the Past: Trends in Executive Compensation over the Twentieth Century, November 2008

2461 Wolfgang Ochel, The Political Economy of Two-tier Reforms of Employment Protection in Europe, November 2008

2462 Peter Egger and Doina Maria Radulescu, The Influence of Labor Taxes on the Migration of Skilled Workers, November 2008

2463 Oliver Falck, Stephan Heblich and Stefan Kipar, The Extension of Clusters: Differencein-Differences Evidence from the Bavarian State-Wide Cluster Policy, November 2008

2464 Lei Yang and Keith E. Maskus, Intellectual Property Rights, Technology Transfer and Exports in Developing Countries, November 2008

2465 Claudia M. Buch, The Great Risk Shift? Income Volatility in an International Perspective, November 2008

2466 Walter H. Fisher and Ben J. Heijdra, Growth and the Ageing Joneses, November 2008

2467 Louis Eeckhoudt, Harris Schlesinger and Ilia Tsetlin, Apportioning of Risks via Stochastic Dominance, November 2008

2468 Elin Halvorsen and Thor O. Thoresen, Parents' Desire to Make Equal Inter Vivos Transfers, November 2008

2469 Anna Montén and Marcel Thum, Ageing Municipalities, Gerontocracy and Fiscal Competition, November 2008

2470 Volker Meier and Matthias Wrede, Reducing the Excess Burden of Subsidizing the Stork: Joint Taxation, Individual Taxation, and Family Splitting, November 2008

2471 Gunther Schnabl and Christina Ziegler, Exchange Rate Regime and Wage Determination in Central and Eastern Europe, November 2008 
2472 Kjell Erik Lommerud and Odd Rune Straume, Employment Protection versus Flexicurity: On Technology Adoption in Unionised Firms, November 2008

2473 Lukas Menkhoff, High-Frequency Analysis of Foreign Exchange Interventions: What do we learn?, November 2008

2474 Steven Poelhekke and Frederick van der Ploeg, Growth, Foreign Direct Investment and Urban Concentrations: Unbundling Spatial Lags, November 2008

2475 Helge Berger and Volker Nitsch, Gotcha! A Profile of Smuggling in International Trade, November 2008

2476 Robert Dur and Joeri Sol, Social Interaction, Co-Worker Altruism, and Incentives, November 2008

2477 Gaëtan Nicodème, Corporate Income Tax and Economic Distortions, November 2008

2478 Martin Jacob, Rainer Niemann and Martin Weiss, The Rich Demystified - A Reply to Bach, Corneo, and Steiner (2008), November 2008

2479 Scott Alan Carson, Demographic, Residential, and Socioeconomic Effects on the Distribution of $19^{\text {th }}$ Century African-American Stature, November 2008

2480 Burkhard Heer and Andreas Irmen, Population, Pensions, and Endogenous Economic Growth, November 2008

2481 Thomas Aronsson and Erkki Koskela, Optimal Redistributive Taxation and Provision of Public Input Goods in an Economy with Outsourcing and Unemployment, December 2008

2482 Stanley L. Winer, George Tridimas and Walter Hettich, Social Welfare and Coercion in Public Finance, December 2008

2483 Bruno S. Frey and Benno Torgler, Politicians: Be Killed or Survive, December 2008

2484 Thiess Buettner, Nadine Riedel and Marco Runkel, Strategic Consolidation under Formula Apportionment, December 2008

2485 Irani Arraiz, David M. Drukker, Harry H. Kelejian and Ingmar R. Prucha, A Spatial Cliff-Ord-type Model with Heteroskedastic Innovations: Small and Large Sample Results, December 2008

2486 Oliver Falck, Michael Fritsch and Stephan Heblich, The Apple doesn't Fall far from the Tree: Location of Start-Ups Relative to Incumbents, December 2008

2487 Cary Deck and Harris Schlesinger, Exploring Higher-Order Risk Effects, December 2008

2488 Michael Kaganovich and Volker Meier, Social Security Systems, Human Capital, and Growth in a Small Open Economy, December 2008 
2489 Mikael Elinder, Henrik Jordahl and Panu Poutvaara, Selfish and Prospective: Theory and Evidence of Pocketbook Voting, December 2008

2490 Maarten Bosker and Harry Garretsen, Economic Geography and Economic Development in Sub-Saharan Africa, December 2008

2491 Urs Fischbacher and Simon Gächter, Social Preferences, Beliefs, and the Dynamics of Free Riding in Public Good Experiments, December 2008

2492 Michael Hoel, Bush Meets Hotelling: Effects of Improved Renewable Energy Technology on Greenhouse Gas Emissions, December 2008

2493 Christian Bruns and Oliver Himmler, It's the Media, Stupid - How Media Activity Shapes Public Spending, December 2008

2494 Andreas Knabe and Ronnie Schöb, Minimum Wages and their Alternatives: A Critical Assessment, December 2008

2495 Sascha O. Becker, Peter H. Egger, Maximilian von Ehrlich and Robert Fenge, Going NUTS: The Effect of EU Structural Funds on Regional Performance, December 2008

2496 Robert Dur, Gift Exchange in the Workplace: Money or Attention?, December 2008

2497 Scott Alan Carson, Nineteenth Century Black and White US Statures: The Primary Sources of Vitamin D and their Relationship with Height, December 2008

2498 Thomas Crossley and Mario Jametti, Pension Benefit Insurance and Pension Plan Portfolio Choice, December 2008

2499 Sebastian Hauptmeier, Ferdinand Mittermaier and Johannes Rincke Fiscal Competition over Taxes and Public Inputs: Theory and Evidence, December 2008

2500 Dirk Niepelt, Debt Maturity without Commitment, December 2008

2501 Andrew Clark, Andreas Knabe and Steffen Rätzel, Boon or Bane? Others' Unemployment, Well-being and Job Insecurity, December 2008

2502 Lukas Menkhoff, Rafael R. Rebitzky and Michael Schröder, Heterogeneity in Exchange Rate Expectations: Evidence on the Chartist-Fundamentalist Approach, December 2008

2503 Salvador Barrios, Harry Huizinga, Luc Laeven and Gaëtan Nicodème, International Taxation and Multinational Firm Location Decisions, December 2008

2504 Andreas Irmen, Cross-Country Income Differences and Technology Diffusion in a Competitive World, December 2008

2505 Wenan Fei, Claude Fluet and Harris Schlesinger, Uncertain Bequest Needs and LongTerm Insurance Contracts, December 2008 
2506 Wido Geis, Silke Uebelmesser and Martin Werding, How do Migrants Choose their Destination Country? An Analysis of Institutional Determinants, December 2008

2507 Hiroyuki Kasahara and Katsumi Shimotsu, Sequential Estimation of Structural Models with a Fixed Point Constraint, December 2008

2508 Barbara Hofmann, Work Incentives? Ex Post Effects of Unemployment Insurance Sanctions - Evidence from West Germany, December 2008

2509 Louis Hotte and Stanley L. Winer, The Demands for Environmental Regulation and for Trade in the Presence of Private Mitigation, December 2008

2510 Konstantinos Angelopoulos, Jim Malley and Apostolis Philippopoulos, Welfare Implications of Public Education Spending Rules, December 2008

2511 Robert Orlowski and Regina T. Riphahn, The East German Wage Structure after Transition, December 2008

2512 Michel Beine, Frédéric Docquier and Maurice Schiff, International Migration, Transfers of Norms and Home Country Fertility, December 2008

2513 Dirk Schindler and Benjamin Weigert, Educational and Wage Risk: Social Insurance vs. Quality of Education, December 2008

2514 Bernd Hayo and Stefan Voigt, The Relevance of Judicial Procedure for Economic Growth, December 2008

2515 Bruno S. Frey and Susanne Neckermann, Awards in Economics - Towards a New Field of Inquiry, January 2009

2516 Gregory Gilpin and Michael Kaganovich, The Quantity and Quality of Teachers: A Dynamic Trade-off, January 2009

2517 Sascha O. Becker, Peter H. Egger and Valeria Merlo, How Low Business Tax Rates Attract Multinational Headquarters: Municipality-Level Evidence from Germany, January 2009

2518 Geir H. Bjønnes, Steinar Holden, Dagfinn Rime and Haakon O.Aa. Solheim, ,Large’ vs. ,Small' Players: A Closer Look at the Dynamics of Speculative Attacks, January 2009

2519 Jesus Crespo Cuaresma, Gernot Doppelhofer and Martin Feldkircher, The Determinants of Economic Growth in European Regions, January 2009

2520 Salvador Valdés-Prieto, The 2008 Chilean Reform to First-Pillar Pensions, January 2009 